\title{
EFFICIENCY MEASUREMENT AND INEFFICIENCY ENVIRONMENTAL FACTORS OF CHINA'S GREEN ECONOMY*
}

\section{Xiaoli Qina,b (D), Jingzheng Wang ${ }^{b}$ (D), Yiping Liu ${ }^{a}$ (D)}

\begin{abstract}
This paper uses the projection pursuit method (PP method) to construct a comprehensive output indicator and uses the heterogeneous stochastic frontier model (HSFM model) to calculate China's green economy efficiency and analyse effects of environmental factors on the inefficiency fluctuation of green economy. Conclusions are drawn as follows: (1) The average value of China's green economy efficiency is generally low, and a regional heterogeneity of green economy efficiency is obvious. (2) For the overall inefficiency fluctuation of China's green economy, openness has a significant inhibitory effect; the industrialization level and technological level have a certain inhibitory effect, but their importance is weaker than that of openness; fiscal decentralization has an insignificant effect. Since 2001, changes in unit openness and the unit industrialization level have had a strengthened restraining effect on the inefficiency fluctuations of China's green economy, and the change in the unit technology level has had a small and stable inhibitory effect on China's green economy's inefficiency fluctuation. (3) Openness and the industrialization level have had a significant inhibitory effect on the inefficiency fluctuation of China's regional green economy in the Eastern region more than in the Central and Western regions; the technological level has had a certain inhibitory effect in the Central and Western regions, but its influence is lower than that of openness. The inhibitory effect of unit change in openness and the industrialization level on the inefficiency fluctuation of green economy in the Central region is greater than that in the Eastern region. The inhibitory effect of unit change in the technological level on the inefficiency fluctuation of green economy in the Western region is obviously greater than that in the Central and Eastern
\end{abstract}

* This paper was supported by Hunan Natural Science Foundation (2019JJ40112), supported by Jiangsu Colleges and universities Philosophy and Social Science Fund project (2021SJA2196), supported by the Jiangsu " 333 High-level Talents Training Project", and also supported by the research and innovation team of Suqian University (2021td06).

a School of Economics and Management, Nanjing University of Aeronautics and Astronautics, Nanjing, Jiangsu, China

b School of Business, Suqian University, Suqian, Jiangsu, China

Email:wjzw767@163.com 
regions. These conclusions can provide a mathematical basis for a reform of China's green economy efficiency.

Keywords: Green economy, efficiency, inefficiency fluctuation, projection pursuit method (PP method), heterogeneous stochastic frontier model (HSFM model)

\section{JEL Classification: O47}

\section{Introduction}

With the evolution from a weak sustainable development view to a strong sustainable development view, the connotation of developing a green economy is no longer limited to ecological governance and economic growth, but has formed a new type of development model, an integration of the three systems of "ecology-economy-society". In 2012, at the "Rio+20" United Nations Conference on Sustainable Development, green economy was widely recognized and responded to as one of the conference themes. In 2016, the "Paris Agreement" was signed and entered into force, which further defined the concept of global climate governance as low-carbon green development (Chen et al., 2020). Under the framework of the green economy concept, more and more countries are committed to improvement of their national energy efficiency strategies, and determine the main priority of green economy. The government of China has also included "green" in its five major development concepts, emphasizing the establishment of a sound economic system for green and low-carbon circular development, and continuously increasing the quality, efficiency and dynamics of economic development. The Fifth Plenary Session of the $19^{\text {th }}$ CPC Central Committee held in October 2020 stressed the need to accelerate green and low-carbon development and comprehensively improve the efficiency of resource use. Under this situation, carrying out research on the environmental factors of green economy efficiency and its inefficiency fluctuations are important for exploring how to effectively promote the efficiency reform of China's green economy development and improve the level of green economic development.

On the whole, at different stages of economic and social development, governments and scholars pay different attention to green economy based on different purposes, which makes understanding of the connotation of green economy biased. At present, efficiencyoriented green economy theory, dominating among the green economy theories, holds that the realization of green economy depends on whether economic growth can offset the loss of resources and environment. It emphasizes the need to improve the efficiency of the economic system to promote the development of green economy, and its core development method is to improve resource utilization efficiency and reduce pollutant emissions to promote the development of green economy. Based on the efficiency-oriented 
green economy theory, this paper makes a narrow understanding of green economy and deems it an economic development model that comprehensively considers economic growth, resource utilization efficiency improvement and environmental pollutant emission reduction. This mode of development mainly focuses on economic and environmental benefits and particularly emphasizes resource conservation and environmental protection as much as possible while developing economy. The contents of this paper are arranged as follows: the second part is a literature review, the third part presents materials and research methods, the fourth part provides an analysis of the empirical results, and the fifth part contains the research conclusions and suggestions.

\section{Literature Review}

Focusing on resources, sustainable consumption and production is the core of green economy principles (Bleischwitz et al., 2018) There are three orientations of efficiency, scale and fairness in the development of green economy, which show different priorities under different conditions and different values, and form different priorities, different green economy theories and policies (Zhu, 2012). At present, there are three main green economy theories in academic circles, namely, efficiency-oriented green economy theory, scale-oriented green economy theory and equity-oriented green economy theory. Among them, efficiency-oriented green economy theory pays more attention to the impact of efficiency, which can be understood as the input-output efficiency including energy consumption and pollutant emissions (Chen and Golley, 2014), leading to active integration of energy indicators into the environmental and economic evaluation system (Matraeva et al., 2017), such as dividing the industrial system energy efficiency indicator system according to different evaluation levels and environmental factors of the "green economy" (Krivorotov et al., 2018). According to the efficiency-oriented green economy theory, green economy efficiency measures the ratio between multiple inputs and multiple outputs. From the perspective of input-output, there are two ways to improve the efficiency of green economy. One is to obtain the maximum economic benefit and produce the minimum environmental pollution under the given condition of resource input; the other is that resource input should be reduced as far as possible under the given condition of economic benefits and environmental pollution. Based on the above analysis, this paper asserts that green economy efficiency is to treat resources and the environment as endogenous variables of economic development, and introduce resources and environmental factors into the efficiency measurement model to comprehensively measure and evaluate the quality of economic development in a certain region, which is a ratio indicator of multiple inputs and multiple outputs. 
In addition, when estimating economic development performance, the lack of consideration of environmental factors will cause the estimated value to be high and distort the evaluation of social welfare changes and economic performance. In academia, there are many studies on the impact of environmental regulations on green economy efficiency (Qian et al., 2015; Zhang et al., 2018; Yin et al., 2020). From the perspective of industrial agglomeration, whether it is cultural industry agglomeration (Liu et al., 2017), logistics industry agglomeration (Wang et al., 2018), high-tech industry agglomeration (Hu et al., 2018), or agglomeration of producer services, that will have an impact on the green economy efficiency. From the perspective of enterprises, the expansion of green economy awareness will promote the improvement of energy efficiency and environmental sustainability (Abdullah et al., 2017; Kasayanond et al., 2019). From the perspective of green economic efficiency research methods, data envelopment analysis (DEA) and stochastic frontier analysis (SFA) have been widely used in practice in the past five years. The DEA method does not depend on the establishment of the growth function and the model changes in various forms. Many improved methods have emerged in the study of green economy efficiency measurement and its environmental factors and impact mechanisms, such as DEA-SBM, DEA-Malmquist, DEA-Tobit (Lin et al., 2019; Shuai et al., 2020), and multi-stage DEA models (Li et al., 2019). However, it is difficult to analyse the elasticity of green economic output relative to various inputs using the DEA method, while the SFA method has statistical characteristics and can decompose the output reasonably. Therefore, the SFA and its improved versions have also been studied in the research applications $(\mathrm{Hu}$ et al., 2017; Bi et al., 2019).

To sum up, the current research into green economy and its efficiency is developing towards refinement, and empirical research and practice-based research methods are also being applied in innovative ways. Compared with the general SFA model, the HSFM model has lower weights for redundant variables when calculating efficiency scores. Moreover, it allows decomposing the efficiency deviation between the random error term and the inefficiency term, which helps reduce the influence of the error on the estimation result. This paper, in line with the requirement to reduce dimensionality of the PP method, constructs a comprehensive output indicator, calculates the green economy efficiency value and analyses influence factors of green economy inefficiency fluctuations and their marginal effect using the HSFM. The specific research objectives of this paper are as follows: (1) The desired output and the undesired output is constructed as a comprehensive output, and the best projection direction is obtained by maximizing the projection indicator function to ensure that China's green economic efficiency measured based on the HSFM has strong robustness, anti-interference and accuracy. (2) The main factors affecting China's green economy inefficiency fluctuations are analysed, the characteristics 
and laws of China's green economy inefficiency fluctuations are revealed, and the reasons for the low level of green economy efficiency in China are explored. (3) Measures to curb the inefficiency fluctuations of the green economy and to improve the efficiency of the green economy steadily are proposed to create a good environment conducive to promoting the development of green economy.

The main research motivations and contributions of this paper are as follows: (1) The comprehensive output level of green economy is calculated using the PP method (a dimension reduction method) to ensure the reliability of the green economy efficiency measurement results. (2) The research conclusions about influence factors of China's green economy inefficiency fluctuations obtained using the HSFM model provide evidence in the opposite direction to explore the reasons for the low level of green economy efficiency in China, which can provide certain mathematical basis to promote China's green economy efficiency change.

\section{Econometric Model and Data Explanation}

\subsection{Data sources, indicator selection and data description}

\subsubsection{Data sources}

Due to the lack of data on Hong Kong, Macao, Taiwan and Tibet, the sample data studied in this paper are panel data of the other 30 provinces, municipalities and autonomous regions in China from 2009 to 2017. All kinds of data mainly come from the EPS database and the "China Statistical Yearbook" and "China Environmental Statistics Yearbook" for each year. To further compare and analyse China's regional green economy efficiency, according to the explanation of China's National Development and Reform Commission, the division into Eastern, Central and Western China is a matter of policy, not an administrative division or a geographical concept. For this reason, the sample provinces (municipalities and autonomous regions) in the Eastern, Central and Western regions are determined based on three considerations. One is provisions of China's "Seventh Five-Year Plan"; the other is Chongqing being set as a municipality (1997) and delimited into the Western region; and the last one is the scope of preferential policies made in 2000 to formulate the Western region development ${ }^{1}$.

1 The Eastern region includes 11 samples: Beijing, Hebei, Tianjin, Liaoning, Shanghai, Zhejiang, Jiangsu, Shandong, Fujian, Hainan and Guangdong; the Central region includes 8 samples: Jilin, Shanxi, Heilongjiang, Jiangxi, Anhui, Hubei, Henan and Hunan; the Western region also includes 11 samples: Inner Mongolia, Guangxi, Chongqing, Guizhou, Sichuan, Gansu, Yunnan, Shaanxi, Qinghai, Xinjiang and Ningxia. 


\subsubsection{Indicator selection}

Based on the existing research results, this paper selects indicators in accordance with the principles of availability, measurability and operability.

\section{(1) Input indicators}

This paper draws on the views of Wang et al., (2015) and Feng et al., (2017) and uses capital, labour and energy as input variables. Capital investment should be measured by capital stock ( $\left.C \_S\right)$, but China has no official capital stock data. For this reason, we refer to the growth rate method determined by Hall and Jones in 1999 to estimate the base period capital stock, and express the base period capital stock as:

$$
C S_{i, 1}=0.5 \times\left(I_{1} /\left(g_{i, 1}+\delta_{i, 1}\right)+I_{1}\left(1+g_{i, 1}\right) /\left(g_{i, 1}+\delta_{i, 1}\right)\right), \quad t=1
$$

The estimation of the capital stock during the reporting period can use the perpetual inventory method, and the estimation can be expressed as:

$$
C S_{i, t}=C S_{i, t-1}\left(1-\delta_{i t}\right)+\left(I_{i, t} / P_{i, t}\right), \quad t=2,3, \ldots, T
$$

Here, the capital stock of the region $i$ in the period $t$ and the period $t-1$ is expressed by $C S_{i, t}$ and $C S_{i, t-1}$ respectively; the investment growth rate of the base period $t$ is expressed by $g_{i, 1}$ and the capital depreciation rate of the base period is expressed by $\delta_{i, 1}$; the capital depreciation rate of the period $t$ is expressed by $\delta_{i t}$, and the fixed asset investment calculated at the current price of the period $t$ is expressed by $I_{i, t}$, the fixed asset investment price indicator of the period $t$ is expressed by $P_{i, t}$.

In the specific calculation, the estimated value of investment growth rate can be determined as the geometric mean of the GDP growth rate of the province or municipality from 2009 to 2013; then, we directly adopt a capital depreciation rate value of $10.96 \%$ estimated by Shan (2008) as the estimated value of $\delta_{i t}$, and use the data of fixed asset investment of the whole society as the value of fixed asset investment $I_{i, t}$. Subsequently, we use Formula (1) to calculate the capital stock $C S_{i, 1}$ with the year 2009 in the base period, use Equation 2 to calculate the capital stock from 2010 to 2017, and use the fixed asset investment price indicator to flatten it to the constant price of 2009.

Labour input should be able to comprehensively reflect factors such as the time, number and efficiency invested by the labour subject in the labour process, but such data are not easy to obtain, so the number of employed persons in urban units at the end of the year $\left(E M \_P\right)$ is used as a substitute indicator. Energy input should reflect the level of utilization of energy resources, and energy consumption $\left(E N_{-} C\right)$ can be used as an energy input indicator to measure the development of a green economy. 


\section{(2) Output indicators}

Since this paper is based on the measurement of China's green economy efficiency, regional GDP $\left(R_{-} G D P\right)$ is selected when measuring the desired output indicator, and we use the CPI indicator to flatten the GDP value to the constant price of 2009. The undesired output in reality mainly comes from industrial production, since the statistical data on industrial waste gas emissions are as of 2010 and the value is low, so industrial wastewater emissions and industrial solid waste emissions are aggregated into the total industrial waste emissions $\left(T N D \_W\right)$. In addition, some missing values are supplemented by linear regression prediction.

\section{(3) Environmental factor indicators}

There are five environmental factor indicators selected in this paper, namely openness, industrialization level, technological level, fiscal decentralization and regional location. For provinces, their degree of openness generally reflects the degree of dependence of the province's economic development on foreign trade, which can be measured by the proportion of total imports and exports to regional GDP ( $\left.I N_{-} E X\right)$; and the proportion of the added value of each industry in the GDP has a trade-off relationship, so the industrialization level of each province can be measured by the proportion of the added value of the secondary industry to regional GDP ( $\left.S E \_I N D\right)$. The technological level, which reflects the strength of regional innovation capability, can be measured by full-time equivalent of R\&D personnel in each province $\left(R_{-} D\right)$; fiscal decentralization reflects the degree of financial autonomy of local governments, and is measured by the proportion of local fiscal revenue to total fiscal revenue ( $L O C_{-} F$ ); regional location can be represented by dummy variables $\left(R_{-} L O C\right)$. This paper assumes that the variable value corresponding to provinces in Western region is 1, that in the Central region is 2, and that in the Eastern region is 3 .

\section{(4) Control indicators}

To more accurately estimate the impact of the above five major environmental factors on the efficiency of green economy, this paper selects two control variables. One is the level of fixed assets, the other is the energy structure. Since fixed assets can effectively expand the space for economic and social development and thus affect the efficiency of green economy, the proportion of fixed asset investment in regional GDP $(F A G G P)$ is chosen to represent the level of fixed assets. The higher the proportion of fossil energy consumption in the total energy consumption in a region, the lower the proportion of renewable and clean energy consumption in the region. Therefore, the proportion of coal in the energy consumption $\left(C C_{-} E N\right)$ is chosen to represent the energy structure. 


\subsubsection{Data description}

The number of samples studied in this paper is 270 . From Table 1, except for the two environmental factor variables, which are $S E_{-} I N D$ and $L O C_{-} F$, the coefficients of variation of the other seven variables are all greater than 0.5 . In particular, the coefficients of variation of the two variables corresponding to $I N_{-} E X$ and $R_{-} D$ in the environmental factor indicators are both greater than 1 , namely 1.171 and 1.437 respectively. All this indicates that the input and output variables of green economy development in the sample provinces ${ }^{2}$ in China are very different; among the environmental factors, $I N_{-} E X$ and $R_{-} D$ are also largely scattered.

Table 1: Description of related indicators, variables and statistical data

\begin{tabular}{|c|c|c|c|c|c|c|}
\hline Type & Indicator & Variable & Unit & Mean & $\begin{array}{l}\text { Standard } \\
\text { deviation }\end{array}$ & $\begin{array}{l}\text { Coefficient } \\
\text { of variation }\end{array}$ \\
\hline \multirow{3}{*}{$\begin{array}{l}\text { Input } \\
\text { indicators }\end{array}$} & $\begin{array}{l}\text { Capital } \\
\text { investment }\end{array}$ & Capital stock $\left(C_{-} S\right)$ & 100 million & $63,682.66$ & $47,720.77$ & 0.749 \\
\hline & $\begin{array}{l}\text { Labour } \\
\text { input }\end{array}$ & $\begin{array}{l}\text { Number of employed per- } \\
\text { sons in urban units at end } \\
\text { of year }\left(E M_{-} P \text { ) }\right.\end{array}$ & thousand & $5,370.42$ & $3,692.13$ & 0.687 \\
\hline & $\begin{array}{l}\text { Energy } \\
\text { input }\end{array}$ & $\begin{array}{l}\text { Energy consumption } \\
\left(E N \_C\right)\end{array}$ & $\begin{array}{l}\text { tonnes } \\
\text { of standard } \\
\text { coal }\end{array}$ & $14,257.98$ & $8,477.94$ & 0.595 \\
\hline \multirow{2}{*}{$\begin{array}{l}\text { Output } \\
\text { indicators }\end{array}$} & $\begin{array}{l}\text { desired } \\
\text { output }\end{array}$ & Regional GDP (R_GDP) & 100 million & $20,030.61$ & $16,093.31$ & 0.803 \\
\hline & $\begin{array}{l}\text { Undesired } \\
\text { output }\end{array}$ & $\begin{array}{l}\text { Total industrial waste } \\
\text { emissions (IND_W) }\end{array}$ & $\begin{array}{l}10 \text { thousand } \\
\text { tonnes }\end{array}$ & $10,056.53$ & $8,778.79$ & 0.873 \\
\hline \multirow{5}{*}{$\begin{array}{l}\text { Environ- } \\
\text { mental } \\
\text { factor } \\
\text { indicators }\end{array}$} & Openness & $\begin{array}{l}\text { Proportion of total imports } \\
\text { and exports to regional } \\
\text { GDP }\left(I N \_E X\right)\end{array}$ & $\%$ & 30.73 & 35.97 & 1.171 \\
\hline & $\begin{array}{l}\text { Industriali- } \\
\text { zation level }\end{array}$ & $\begin{array}{l}\text { Proportion of added value } \\
\text { of secondary industry } \\
\text { to regional GDP (SE_IND) }\end{array}$ & $\%$ & 46.03 & 8.30 & 0.180 \\
\hline & $\begin{array}{l}\text { Technologi- } \\
\text { cal level }\end{array}$ & $\begin{array}{l}\text { Full-time equivalent of } \mathrm{R} \& \mathrm{D} \\
\text { personnel }\left(R_{-} D\right)\end{array}$ & Person-year & $11,640.26$ & $16,722.68$ & 1.437 \\
\hline & $\begin{array}{l}\text { Fiscal decen- } \\
\text { tralization }\end{array}$ & $\begin{array}{l}\text { Proportion of local fiscal } \\
\text { revenue }\left(L O C_{-} F\right)\end{array}$ & $\%$ & 32.44 & 11.99 & 0.370 \\
\hline & $\begin{array}{l}\text { Regional } \\
\text { location }\end{array}$ & Dummy variables $\left(R_{-} L O C\right)$ & & & & \\
\hline \multirow{2}{*}{$\begin{array}{l}\text { Control } \\
\text { indicators }\end{array}$} & $\begin{array}{l}\text { Fixed } \\
\text { assets }\end{array}$ & $\begin{array}{l}\text { Proportion of fixed } \\
\text { asset investment in GDP } \\
\left(F A_{-} G D P\right)\end{array}$ & $\%$ & 76.66 & 23.36 & 0.300 \\
\hline & $\begin{array}{l}\text { Energy } \\
\text { structure }\end{array}$ & $\begin{array}{l}\text { Proportion of coal } \\
\text { in energy consumption } \\
\left(C_{-} E N\right)\end{array}$ & $\%$ & 19.17 & 17.98 & 0.940 \\
\hline
\end{tabular}

Source: EPS database, China Statistical Yearbook and China Environmental Statistics Yearbook

2 Province here and hereinafter is a general term for province, municipality and autonomous region. 


\subsection{Research methods}

\subsubsection{Projection pursuit method (PP method)}

The PP method can reduce the dimension of complex output indicator data and retain the structural characteristics of the original high-dimensional data, so as to make up for the defect of the stochastic frontier model which can only deal with multi-input and single-output indicators. The principle of the PP method is to decompose the highdimensional data into multiple factors, which are reflected in the low-dimensional subspace in the form of local scattered points using the projection indicator function. The projection points represent the structural characteristics of high-dimensional data, and the density of projection points indicates the possibility of factor distribution, that is, the probability of reflecting the integrity of the original data of each dimension. The most locally dense and globally dispersed part of the projection point is the best projection direction. The projection values of the original data of each dimension can be obtained by calculation. Its modelling process is as follows:

Step 1: the construction of projection data. Suppose $n$ is the number of samples, $m$ is the number of indicators, and $X_{i j}(i=1,2, \ldots, n ; j=1,2, \ldots, m)$ is the $j^{\text {th }}$ output indicator value of the sample $i$. Since the value and unit of each output indicator are not uniform, it is necessary to standardize $X_{i j}$ to a value $x_{i j}$ in the interval $[0,1]$.

Step 2: the construction of the projection objective function. Assuming that $\mathrm{P}=\left(p_{1}, p_{2}, \ldots, p_{m}\right)$ is the best projection direction, we can use Formula (3) to linearly project $x_{i j}$ into a one-dimensional variable:

$$
z_{i}=\sum_{j=1}^{m} p_{j} x_{i j}, \quad i i=1,2, \ldots, n n
$$

Here, $z_{i}$ is the projection value.

The projection objective function can be constructed: $Q=s(P) \times d(P)$

Here, $s(P)$ represents the distance of the level, that is, the standard dispersion degree; $d(P)$ reflects the density of each category.

Step 3: optimization of the projection objective function. When the output indicator is determined, the best projection direction $P^{*}$ can be obtained by optimizing the model constructed by Formula (5):

$$
Q_{\max }=s(P) \times d(P) \quad \text { sst. } \sum_{j=1}^{m} p_{j}^{2}=p
$$

To achieve the global optimal solution, this paper uses the real-coded accelerating genetic algorithm (RAGA) based on real-coding to optimize the multi-dimensional projection direction. 
Step 4: Calculation of the best projection value. The optimal projection value $z_{i}^{*}$ of each sample can be obtained by substituting the optimal projection direction $P^{*}$ into Formula (3).

\subsubsection{HSFM constructed}

In practice, the SFA model widely uses the maximum likelihood estimation method (MLE) to estimate the parameters, but the random interference term and the inefficiency term in the mixed error term may have heteroscedasticity, so it is necessary to analyse the effect of heteroscedasticity on the efficiency measurement. Guermat et al. (1999) conducted Monte Carlo experiments on the semi-normal stochastic production frontier and found that when heteroscedasticity exists, modifying it can significantly improve the statistical properties of the estimator and improve the accuracy of the efficiency measurement results. This paper draws on the heterogeneous stochastic frontier analysis proposed by Wang (2003), and its output model expression is:

$$
\text { output }_{i t}=f\left(\text { inputs }_{i t} ; \beta\right) \times \exp \left\{-\boldsymbol{u}_{i i t}\right\} \times \exp \left\{v_{\text {itit }}\right\}
$$

Here, $i=1,2, \ldots, N, t=1,2, \ldots, T . f\left(\right.$ inputs $\left._{i t} ; \beta\right)$ is the production function, output ${ }_{i t}$ and inputs $_{i t}$ is the output indicator and input indicator vector of the evaluation object $i$ at the time $t$, respectively, is the coefficient vector to be estimated. When the assumption $\ln \left(f\left(\right.\right.$ inputs $\left.\left._{i t} ; \beta\right)\right)=a_{0}+\ln$ inputs $_{i t} \beta$ ( $a_{0}$ is the constant term to be estimated $)$ is in log-linear form, the stochastic frontier model becomes $\ln$ output $_{i t}=a_{0}+\ln$ inputs $_{i t} \beta+v_{i t}-u_{i t}$. At this time, the mixed error term $\varepsilon_{i t}$ can be defined as:

$$
\varepsilon_{i t}=\ln \text { output }_{i t}-a_{0}-\ln \text { inputs }_{i t} \beta=v_{i t}-u_{i t}
$$

Here, $v_{i t}$ is the uncontrollable random error term in the production activities, assuming the random error term $v_{i t} \sim$ i.i.d. $N\left(0, \sigma_{v}^{2}\right)$; the inefficiency term $u_{i t} \geq 0$, which has the characteristics of unilateral distribution, is used to measure the difference between the actual output of the evaluation object $i$ at the time $t$ and the output of the production frontier. If $u_{i t}$ is heterogeneous, it can be assumed to obey a non-negative truncated halfnormal distribution, which means $u_{i t} \sim$ i.i.d. $N^{+}\left(w_{u, i t}, \sigma_{u, i t}^{2}\right)$. To ensure, $\sigma_{u, i t}^{2} \geq 0, w_{u, i t} \geq 0$ the heterogeneity of $u_{i t}$ is set as follows:

$$
w_{u, i t}=\exp \left(b_{0}+Z_{i t}^{\prime} \delta\right) \quad \text { And } \sigma_{u, i t}^{2}=\exp \left(b_{1}+Z_{i t}^{\prime} \eta\right)
$$

$b_{0}$ and $b_{1}$ are constant, $\delta$ and $\eta$ are vectors of coefficients to be estimated, $Z_{i t}$ is a vector of environmental variables that may cause heteroscedasticity. 
When the mixed error term $\varepsilon_{i t}$ assumes heteroscedasticity, its density function is:

$$
f_{i t}\left(\varepsilon_{i t}\right)=\frac{2}{\sigma_{i t}} \phi\left(\frac{\varepsilon_{i t}}{\sigma_{i t}}\right)\left[1-\Phi\left(\frac{\varepsilon_{i t} \lambda_{i t}}{\sigma_{i t}}\right)\right],-\infty<\varepsilon_{i t}<\infty
$$

Here, $\sigma_{i t}=\left(\sigma_{u, i t}^{2}+\sigma_{v}^{2}\right)^{1 / 2}, \lambda_{i t}=\sigma_{u, i t} / \sigma_{v}, \phi$ and $\Phi$ are the probability density function and cumulative distribution function of the standard normal distribution. $a_{0}, b_{0}, b_{1}, \delta$, $\eta$ and $\sigma_{v}^{2}$ in Equations 7,8 and 9 can be estimated using the maximum likelihood estimation method.

For the ordinary SFA model under the assumption of non-heterogeneity, $\sigma_{u}^{2}$ and $\sigma_{v}^{2}$ are constant, and the indicator $\gamma=\sigma_{u}^{2} /\left(\sigma_{u}^{2}+\sigma_{v}^{2}\right)$ can be calculated. If $\gamma \rightarrow 1$, which shows that the fluctuation of the inefficiency item accounts for a large proportion of the total fluctuation, so the SFA model should be used for estimation at this time. If $\gamma \rightarrow 0$, the SFA method is not required for estimation, and the ordinary least squares (OLS) can be used for estimation directly.

The expression $E I$ can be obtained from Formula (6). The value of $E I$ is between 0 and 1 , when $E I=0\left(u_{i t} \rightarrow \infty\right)$, it means the most inefficient, and $E I=1,\left(u_{i t}=0\right)$ it means the most efficient.

In addition, the unconditional statistics of the mean $u_{i t}$ and the variance are $E\left(u_{i t}\right)$ and $V\left(u_{i t}\right)$ respectively. In this paper, the marginal effect represents the change in the explained variable when the explanatory variable changes. By $\delta$, estimated according to Equation 8, the marginal effect $V\left(u_{i t}\right)$ of the environmental variable vector $Z_{i t}$ pair is shown in Equation 10:

$$
\begin{aligned}
& \frac{\partial V\left(u_{i t}\right)}{\partial z_{k}}=\frac{\delta_{k}}{\sigma_{u, i t}}\left[\frac{\phi(\Lambda)}{\Phi(\Lambda)}\right]\left(m_{1}^{2}+m_{2}\right)+\eta_{k} \sigma_{u, i t}^{2}\left[1-0.5\left[\frac{\phi(\Lambda)}{\Phi(\Lambda)}\right]\left[\begin{array}{l}
\Lambda+\Lambda^{3}+(2+3 \Lambda) \\
\Phi(\Lambda)
\end{array} \quad+2 \Lambda\right.\right. \\
& \left.\left.+\left(2+3 \Lambda^{2}\right)\left[\frac{\phi(\Lambda)}{\Phi(\Lambda)}\right]+2 \Lambda\left[\frac{\phi(\Lambda)}{\Phi(\Lambda)}\right]^{2}\right]\right] \\
& \text { Here, } \Lambda=w_{u, i t} / \sigma_{u, i t}, m_{1}=\sigma_{u, i t}\left[\Lambda+\frac{\phi(\Lambda)}{\Phi(\Lambda)}\right], \text { and } m_{2}=\sigma_{u, i t}^{2}\left[1-\Lambda\left[\frac{\phi(\Lambda)}{\Phi(\Lambda)}\right]+\left[\frac{\phi(\Lambda)}{\Phi(\Lambda)}\right]^{2}\right]
\end{aligned}
$$

are the first and second moment of $u_{i t}$ respectively. 


\subsection{Calculation of comprehensive output and HSFM form selection}

\subsubsection{Calculation of value of green economy comprehensive output based on PP method}

In Formula (6), it can be seen that there can only be one output variable on the left side of the equation, while there can be multiple input variables on the right side, which is similar to multiple regression in form. In this paper, when measuring green economy efficiency, two output variables are selected, namely GDP of the region $\left(R_{-} G D P\right)$ as desired output and total industrial waste emission (IND_W) as undesirable output (see Table 1). At this time, the model cannot be used directly to measure according to Formula (6), because there are two output variables, which is inconsistent with the premise that only one output variable can exist in the model. The solution to this problem is to use the PP method, which converts two output variables into a single composite output variable. This paper attempts to convert regional GDP $\left(R_{-} G D P\right)$ as desired output and total industrial waste emissions $\left(I N D \_W\right)$ as undesired output into a single comprehensive output variable (see Table 2), thus making up for the defect that the stochastic frontier model can only deal with multiinput and single-output. From this perspective, the PP method can reduce the dimension of complex output indicator data and retain the structural characteristics of original highdimensional data (Huber, 1985).

Traditional research usually only considers desired output. When measuring green economy efficiency, it is necessary to consider the impact of undesired output. According to the projection pursuit method, we use the software MATLAB_R2016a to compile the program, and import the data of $\left(R \_G D P\right)$ and $\left(I N D \_W\right)$ for sample provinces from 2009 to 2017 to calculate the best projection direction year by year. The best projection value is the comprehensive output level of the green economy. In this way, two output variables can be transformed into a comprehensive output variable, that is, the comprehensive output level of green economy. (See Appendix 1 for more detailed statistical results on regional GDP as desired output $\left(R \_G D P\right)$, total industrial waste emissions as undesired output $\left(I N D \_W\right)$ and comprehensive output variables). Due to the limitation of space, this paper only separately lists the mean and rank of comprehensive output and regional GDP of all sample provinces for comparison purposes (see Table 2). Comparing the comprehensive output ranks that consider undesired output and the GDP ranks of regions that only consider desired output, it is found that there are 5 provinces with remaining original ranks, namely Shandong, Guangdong, Guangxi, Jiangsu and Zhejiang; there are 14 places that have risen in rank, such as Shanghai, Beijing, Hunan, etc.; 9 places that have fallen in rank, such as Yunnan, Sichuan and Anhui. It can be seen that whether undesired output 
is considered will have great impact on the efficiency of the green economy. At the same time, there is a large regional difference in the mean value of comprehensive output of the green economy in Table 2 .

Table 2: Mean and rank of comprehensive output and regional GDP (2009-2017)

\begin{tabular}{|c|c|c|c|c|c|c|c|c|c|}
\hline \multirow{2}{*}{ Province } & \multicolumn{2}{|c|}{$\begin{array}{c}\text { Comprehensive } \\
\text { output }\end{array}$} & \multicolumn{2}{|c|}{$\begin{array}{c}\text { Regional GDP } \\
\text { (100 million yuan) }\end{array}$} & \multirow{2}{*}{ Province } & \multicolumn{2}{|c|}{$\begin{array}{c}\text { Comprehensive } \\
\text { output }\end{array}$} & \multicolumn{2}{|c|}{$\begin{array}{c}\text { Regional GDP } \\
\text { (100 million yuan) }\end{array}$} \\
\hline & Mean & Rank & Mean & Rank & & Mean & Rank & Mean & Rank \\
\hline Guangdong & 1.11 & 1 & $60,471.64$ & 1 & Anhui & 0.48 & 16 & $18,218.26$ & 14 \\
\hline Jiangsu & 1.01 & 2 & $58,019.80$ & 2 & Shaanxi & 0.47 & 17 & $15,112.25$ & 15 \\
\hline Shandong & 0.86 & 3 & $52,936.88$ & 3 & Guangxi & 0.47 & 18 & $13,590.31$ & 18 \\
\hline Zhejiang & 0.81 & 4 & $36,112.26$ & 4 & Jiangxi & 0.43 & 19 & $13,796.97$ & 17 \\
\hline Shanghai & 0.64 & 5 & $21,596.47$ & 11 & Hainan & 0.41 & 20 & $3,002.43$ & 28 \\
\hline Henan & 0.62 & 6 & $31,199.20$ & 5 & Xinjiang & 0.39 & 21 & $7,783.50$ & 26 \\
\hline Beijing & 0.62 & 7 & $19,044.54$ & 13 & Gansu & 0.39 & 22 & $5,814.56$ & 27 \\
\hline Hunan & 0.61 & 8 & $23,586.73$ & 9 & Liaoning & 0.39 & 23 & $22,990.91$ & 10 \\
\hline Hubei & 0.60 & 9 & $23,966.71$ & 8 & Guizhou & 0.38 & 24 & $7,979.34$ & 25 \\
\hline Fujian & 0.58 & 10 & $21,084.81$ & 12 & Ningxia & 0.37 & 25 & $2,442.85$ & 29 \\
\hline Sichuan & 0.56 & 11 & $25,309.72$ & 7 & Yunnan & 0.37 & 26 & $11,135.32$ & 24 \\
\hline Tianjin & 0.53 & 12 & $13,336.78$ & 19 & Hebei & 0.34 & 27 & $26,389.67$ & 6 \\
\hline Chongqing & 0.50 & 13 & $12,408.82$ & 21 & $\begin{array}{l}\text { Inner } \\
\text { Mongolia }\end{array}$ & 0.31 & 28 & $14,988.67$ & 16 \\
\hline Heilongjiang & 0.48 & 14 & $13,209.50$ & 20 & Qinghai & 0.27 & 29 & $1,995.25$ & 30 \\
\hline Jilin & 0.48 & 15 & $11,886.36$ & 22 & Shanxi & 0.2 & 30 & $11,507.66$ & 23 \\
\hline
\end{tabular}

Source: EPS database, China Statistical Yearbook and China Environmental Statistics Yearbook

\subsubsection{HSFM form selection}

Based on the selection of production function form, this paper determines the suitable form of HSFM. The model fitting is mainly based on the software Stata 15, and all the variables involved are logarithmic except for regional dummy variables. 
(1) Selection of production function form

In Table 3, by comparing the determination coefficient $R^{2}(0.264<0.675)$ of $\mathrm{M}_{1}$ and $\mathrm{M}_{2}$, it is found that the fitting degree of $\mathrm{M}_{2}$ is better than that of $\mathrm{M}_{1}$. Therefore, the Translog production function is preliminarily selected as the specific form of production function analysed in this paper. To further verify the rationality of the model form setting, the null hypothesis $\left(\mathrm{H}_{0}\right)$ is formulated: the coefficients of $\ln \left(C_{-} S\right) \times \ln \left(C_{-} S\right)$ and $\ln \left(C_{-} S\right) \times \ln \left(E M_{-} P\right)$ are 0 . A likelihood ratio test ( $L R$ test) is applied to test the null hypothesis, and the test statistic $L R$ approximately obeys the mixed chi-square distribution that the confidence level is $\alpha$ and the degree of freedom is $k$, namely $L R \sim \chi_{1-\alpha}^{2}(k)$. The expression of the test statistic $L R$ is:

$$
L R=-2 \times\left[\ln L\left(H_{0}\right)-\ln L\left(H_{1}\right)\right]
$$

Here, $L\left(H_{0}\right)$ and $L\left(H_{1}\right)$ respectively represent logarithmic likelihood function values under the null hypothesis and the alternative hypothesis. It can be seen from Table 3 that the likelihood rate of $\mathrm{M}_{2}$ is 12.14 , which is greater than the critical value 6.63 at the significance level of $1 \%$, so the null hypothesis is rejected. Therefore, the model in the form of the Translog production function is more suitable for fitting the sample data of green economy efficiency level.

The Translog function was also adopted by $\mathrm{M}_{3}, \mathrm{M}_{4}$ and $\mathrm{M}_{5}$. It was found that the size and direction of the regression coefficients did not change significantly by observing the regression results of these three models, so the Translog function was finally chosen as the production function form.

\section{(2) HSFM form selection}

In Table $3, \mathrm{M}_{4}$ and $\mathrm{M}_{5}$ are based on $\mathrm{M}_{3}$ and adopt the HSFM method to consider the estimation and test results of the influence of environmental variables on the fluctuation of inefficiency items. From the log-likelihood value, the value of $\mathrm{M}_{3}$ is -222.698 , which is smaller than -172.977 , both the value of $M_{3}$ and the value of $M_{4}$ are smaller than -162.371 , the value of $\mathrm{M}_{5}$, indicating that $\mathrm{M}_{5}$ has the best fitting effect. To further determine the reliability of $\mathrm{M}_{5}$, the likelihood ratio test ( $L R$ test) is still required. The original hypothesis $\left(H_{0}\right)$ of the likelihood ratio test LR is that "environmental factors do not have a heterogeneous influence on the inefficiency of the green economy".

In Table 3, the likelihood ratio of 117.910 of $\mathrm{M}_{5}$ is greater than the critical value of at the $1 \%$ significance level. Therefore, the null hypothesis of likelihood is rejected. So, we choose $\mathrm{M}_{5}$ as a basis to measure China's green economy efficiency level. 
Table 3: Estimation of OLS, SFA and HSFM

\begin{tabular}{|c|c|c|c|c|c|}
\hline Estimation $\operatorname{Model}\left(\mathrm{M}_{\mathrm{i}}\right)$ & $M_{1}:$ OLS & $M_{2}:$ OLS & $M_{3}:$ SFA & $M_{4}:$ HSFM & $\begin{array}{c}M_{5}: \text { HSFM } \\
\text { (Control variable) }\end{array}$ \\
\hline Production function & C-D & Translog & Translog & Translog & Translog \\
\hline $\ln \left(C_{-} S\right)$ & $\begin{array}{c}0.112 \\
(-0.99)\end{array}$ & $\begin{array}{l}3.285^{* *} \\
(-2.99)\end{array}$ & $\begin{array}{l}5.293^{* * * *} \\
(-6.41)\end{array}$ & $\begin{array}{l}5.025^{* * *} \\
(-7.03)\end{array}$ & $\begin{array}{l}4.954^{* * *} \\
(-7.00)\end{array}$ \\
\hline $\ln \left(E M \_P\right)$ & $\begin{array}{l}0.666^{* * *} \\
(-5.78)\end{array}$ & $\begin{array}{l}-4.451^{* *} \\
(-3.15)\end{array}$ & $\begin{array}{l}-6.805^{* * *} \\
(-6.45)\end{array}$ & $\begin{array}{l}-6.510 * * * \\
(-7.25)\end{array}$ & $\begin{array}{l}-6.447^{* * *} \\
(-7.26)\end{array}$ \\
\hline $\ln \left(E n \_C\right)$ & $\begin{array}{l}-0.367^{* *} \\
(-2.86)\end{array}$ & $\begin{array}{l}-0.414^{* *} \\
(-3.29)\end{array}$ & $\begin{array}{l}-0.434^{* * *} \\
(-5.05)\end{array}$ & $\begin{array}{l}-0.364^{* * *} \\
(-4.71)\end{array}$ & $\begin{array}{l}-0.362^{* * *} \\
(-4.57)\end{array}$ \\
\hline $\ln \left(C_{-} S\right) \times \ln \left(C_{-} S\right)$ & $\begin{array}{l}- \\
-\end{array}$ & $\begin{array}{c}-0.335^{* *} \\
(-3.28)\end{array}$ & $\begin{array}{l}-0.481^{* * *} \\
(-6.29)\end{array}$ & $\begin{array}{l}-0.454^{* * *} \\
(-6.91)\end{array}$ & $\begin{array}{l}-0.446^{* * *} \\
(-6.85)\end{array}$ \\
\hline $\ln \left(C_{-} S\right) \times \ln \left(E M \_P\right)$ & - & $\begin{array}{l}0.485^{* * *} \\
(-3.65)\end{array}$ & $\begin{array}{l}0.662^{* * *} \\
(-6.62)\end{array}$ & $\begin{array}{l}0.622^{* * *} \\
(-7.39)\end{array}$ & $\begin{array}{l}0.614^{* * *} \\
(-7.38)\end{array}$ \\
\hline _cons & $\begin{array}{l}-4.178^{* * *} \\
(-6.93)\end{array}$ & $\begin{array}{l}- \\
-\end{array}$ & $\begin{array}{l}- \\
-\end{array}$ & $\begin{array}{l}- \\
-\end{array}$ & - \\
\hline
\end{tabular}

Fluctuation of random error term $\left(\ln \sigma_{v}{ }^{2}\right)$

\begin{tabular}{l|c|c|c|c|c}
\hline \multirow{2}{*}{ cons } & - & - & $3.673^{* * *}$ & $-2.811^{* * *}$ & $-2.785^{* * *}$ \\
& - & - & $(-5.97)$ & $(-14.81)$ & $(-14.81)$ \\
\hline
\end{tabular}

Fluctuation of inefficiency term $\left(\ln \sigma_{u, i t}^{2}\right)$

\begin{tabular}{|c|c|c|c|c|c|}
\hline $\ln \left(I N \_E X\right)$ & - & - & - & $\begin{array}{l}-0.556 * * * \\
(-3.76)\end{array}$ & $\begin{array}{l}-0.501^{* * *} \\
(-3.16)\end{array}$ \\
\hline $\ln \left(S E \_I N D\right)$ & - & - & $\begin{array}{l}- \\
-\end{array}$ & $\begin{array}{c}-0.903^{* *} \\
(-2.16)\end{array}$ & $\begin{array}{c}-0.946^{* *} \\
(-2.20)\end{array}$ \\
\hline $\ln \left(R \_D\right)$ & - & - & - & $\begin{array}{c}-0.185^{* *} \\
(-2.14)\end{array}$ & $\begin{array}{c}-0.176^{* *} \\
(-1.96)\end{array}$ \\
\hline $\ln \left(L O C_{-} F\right)$ & - & - & - & $\begin{array}{c}0.151 \\
(-0.44) \\
\end{array}$ & $\begin{array}{l}-0.042 \\
(-0.11)\end{array}$ \\
\hline Local & - & $\begin{array}{l}- \\
- \\
\end{array}$ & - & $\begin{array}{l}4.293^{* * *} \\
(-3.15) \\
\end{array}$ & $\begin{array}{l}3.913^{* * * *} \\
(-4.03)\end{array}$ \\
\hline _cons & - & - & $\begin{array}{c}-0.035^{*} \\
(-0.28)\end{array}$ & - & - \\
\hline $\ln \left(C C_{-} E N\right)$ & - & - & - & - & $\begin{array}{l}0.529 * \\
(-1.80)\end{array}$ \\
\hline $\ln \left(F A \_G D P\right)$ & - & - & - & - & $\begin{array}{c}-0.216^{*} \\
(-1.94)\end{array}$ \\
\hline \multicolumn{6}{|c|}{ Mean of inefficiency terms $\left(\ln w_{u, i t}\right)$} \\
\hline cons & - & - & - & $\begin{array}{c}-176.886 \\
(-0.45)\end{array}$ & $\begin{array}{c}-117.276 \\
(-1.11)\end{array}$ \\
\hline $\mathbf{N}$ & 270 & 270 & 270 & 270 & 270 \\
\hline Log likelihood & -279.726 & -273.658 & -222.698 & -166.689 & -163.743 \\
\hline$R^{2}$ & 0.264 & 0.675 & - & - & - \\
\hline $\boldsymbol{r}$ & - & - & 0.974 & - & - \\
\hline LR & - & 12.140 & - & 112.020 & 117.910 \\
\hline$p$-value & - & 0.000 & - & 0.000 & 0.000 \\
\hline
\end{tabular}

Note: $(1){ }^{* * *},{ }^{*}$ and ${ }^{*}$ mean it is significant at the levels of $1 \%, 5 \%$, and $10 \%$, respectively. The $t$ value is in parentheses; (2) $L R$ is the chi-square value obtained by the test of likelihood ratio of $M_{2}$ to $M_{1}, M_{4}$ to $M_{3}$ and $M_{5}$ to $M_{3}$. Source: Own analysis 
The regression results of $\mathrm{M}_{5}$ show that the first-order coefficient of $\operatorname{Ln}\left(C_{-} S\right)$ is significantly positive, indicating that an increase in capital stock has a significant promoting effect on the comprehensive output of green economy. Meanwhile, the second-order coefficient of $\operatorname{Ln}\left(C_{-} S\right) \times \operatorname{Ln}\left(C_{-} S\right)$ is significantly negative, indicating that an increase in capital stock has a decreasing promoting effect on the comprehensive output of green economy. The coefficients $\operatorname{Ln}\left(E M_{-} P\right)$ and $\operatorname{Ln}\left(E N_{-} C\right)$ are both significantly negative, indicating that an increase in labour input and energy input has a significant inhibiting effect on the comprehensive output of green economy. The coefficients of interaction terms $\operatorname{Ln}\left(C_{-} S\right) \times \operatorname{Ln}\left(E M_{-} P\right)$ are both significantly positive, indicating that capital input and labour input play an effective and benign role in the process of improving the comprehensive output of green economy.

\section{Empirical Result Analysis}

\subsection{Measurement and evaluation of China's green economy efficiency value}

\subsubsection{Average value of green economy efficiency of each province}

Table 4 is the average green economic efficiency of sample provinces in China calculated on the basis of Model 5 in Table 3 (see Appendix 2 for more detailed data). By analysing the data in Table 4, some valuable messages can be found. Firstly, the average value of the green economy efficiency of all sample provinces is less than 1, indicating that the comprehensive output of each province is not the most effective under the condition of constant capital, labour and energy inputs. China's overall green economy efficiency average is low, at 0.702 , and there is much room for improvement. Secondly, the top places with the higher average green economy efficiency are mainly concentrated in the Eastern region, of which 6 places have an average value greater than 0.8 , formed by the Beijing-Shandong-Jiangsu-Zhejiang-Shanghai-Guangdong contiguous distribution belt. Among them, Shanghai has the highest total average green economy efficiency, reaching 0.912 , indicating that its green economy development is at the leading level in China. The third is that the average green economic efficiency of provinces with resource-based economic growth models is generally low, such as Ningxia, Qinghai, Shanxi and Hebei. 
Table 4: Average green economic efficiency of China's provinces (2009-2017)

\begin{tabular}{l|l|l|l|l|l|l|l|c}
\hline Province & Mean & Rank & Province & Mean & Rank & Province & Mean & Rank \\
\hline Shanghai & 0.912 & 1 & Sichuan & 0.756 & 11 & Jilin & 0.652 & 21 \\
\hline Guangdong & 0.890 & 2 & Xinjiang & 0.755 & 12 & Yunnan & 0.641 & 22 \\
\hline Jiangsu & 0.855 & 3 & Heilongjiang & 0.737 & 13 & Liaoning & 0.627 & 23 \\
\hline Beijing & 0.849 & 4 & Guizhou & 0.720 & 14 & Inner Mongolia & 0.619 & 24 \\
\hline Zhejiang & 0.826 & 5 & Chongqing & 0.704 & 15 & Jiangxi & 0.603 & 25 \\
\hline Shandong & 0.808 & 6 & Shaanxi & 0.690 & 16 & Hebei & 0.586 & 26 \\
\hline Fujian & 0.798 & 7 & Guangxi & 0.689 & 17 & Hainan & 0.568 & 27 \\
\hline Hunan & 0.787 & 8 & Henan & 0.688 & 18 & Ningxia & 0.523 & 28 \\
\hline Hubei & 0.783 & 9 & Anhui & 0.672 & 19 & Shanxi & 0.483 & 29 \\
\hline Tianjin & 0.756 & 10 & Gansu & 0.658 & 20 & Qinghai & 0.436 & 30 \\
\hline
\end{tabular}

Source: Own analysis

\subsubsection{Perspective of green economy efficiency value of each region}

According to the classification standards of the three regions in China and the data in Appendix 2, the green economic efficiency calculated of China's three major regions is shown in Table 5. It can be seen from Table 5 that the average value of green economy efficiency in the Eastern region is 0.770 , which is significantly higher than the national average value of 0.702 ; while the average value of 0.669 in the Central region and 0.657 in the Western region are lower than the national average.

Table 5: Green economy efficiency values of China's three major regions (2009-2017)

\begin{tabular}{l|l|l|l|l|l|l|l|l|l|l}
\hline Region & $\mathbf{2 0 0 9}$ & $\mathbf{2 0 1 0}$ & $\mathbf{2 0 1 1}$ & $\mathbf{2 0 1 2}$ & $\mathbf{2 0 1 3}$ & $\mathbf{2 0 1 4}$ & $\mathbf{2 0 1 5}$ & $\mathbf{2 0 1 6}$ & $\mathbf{2 0 1 7}$ & Mean \\
\hline Western & 0.582 & 0.642 & 0.535 & 0.803 & 0.748 & 0.689 & 0.852 & 0.223 & 0.839 & 0.657 \\
\hline Central & 0.637 & 0.694 & 0.657 & 0.807 & 0.747 & 0.706 & 0.701 & 0.378 & 0.696 & 0.669 \\
\hline Eastern & 0.802 & 0.828 & 0.795 & 0.869 & 0.833 & 0.806 & 0.680 & 0.573 & 0.748 & 0.770 \\
\hline National & 0.679 & 0.726 & 0.667 & 0.829 & 0.779 & 0.737 & 0.744 & 0.398 & 0.763 & 0.702 \\
\hline
\end{tabular}

Source: Own analysis 
If we combine the data in Table 5 with the trend line in Figure 1, the regional heterogeneity of green economic efficiency is very significant. Obviously, except for the green economy efficiency value of the Eastern region in 2015, which was lower than that of the Central and Western regions, it was higher than that of the Central and Western regions in other periods; the green economic efficiency values of the three major regions (Eastern, Central and Western) fluctuated between 2009 and 2015. The trends are similar and relatively stable, but they all fell sharply in 2016 and returned to near the average in 2017. A possible explanation is that China's environmental protection inspections were fully launched in 2016, which put a heavy pressure on energy demand and emissions. At the same time, in 2016, China's traditional resource-based industries entered the deep adjustment zone. With the official announcement of the domestic industrial structure adjustment policy and the "Belt and Road" plan, its policy effects began to show in 2017.

Figure 1: Green economy efficiency value map of China's three major regions (2009-2017)

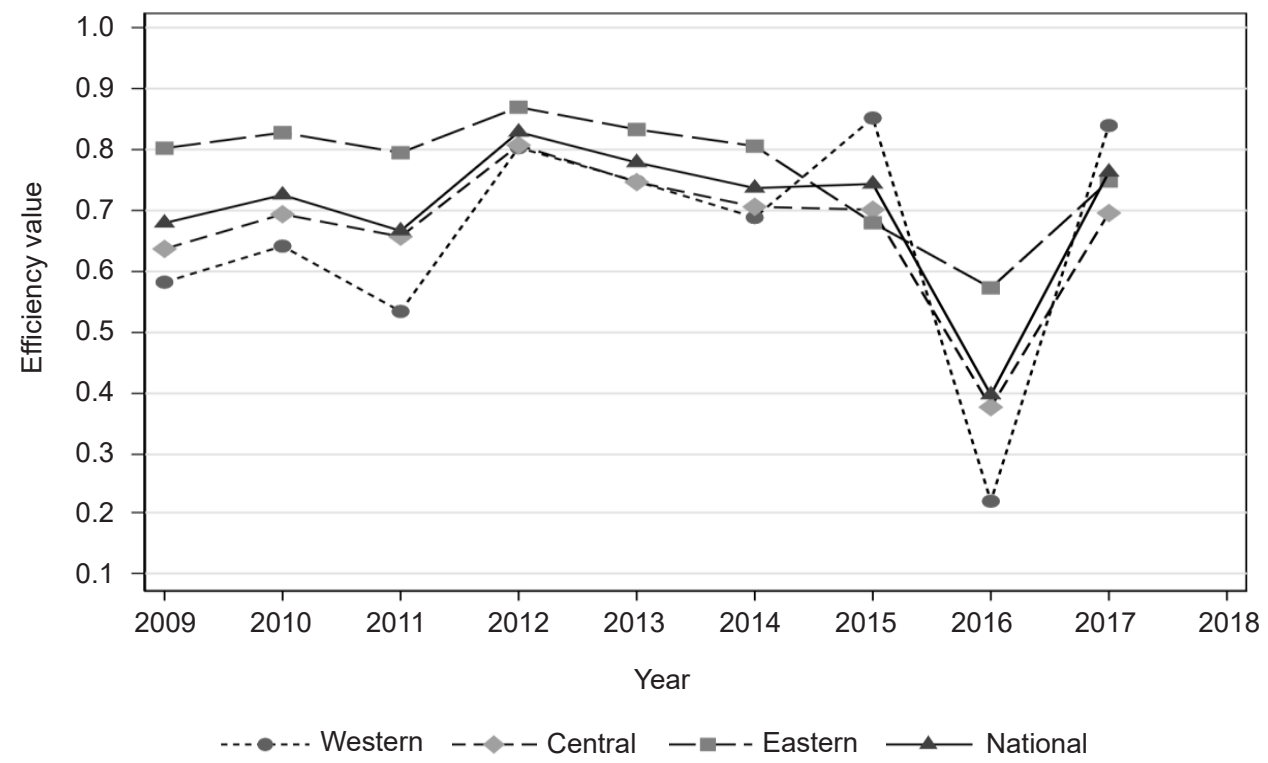

Source: Own analysis

\subsubsection{Robustness test}

To ensure the reliability of the basic estimation results, the following robustness tests are carried out. 
(1) Changing environmental variables measured

This is shown in Table 6. Foreign capital dependence $\left(F_{-} C\right)$ is used to express the degree of economic openness. It is calculated by converting foreign direct investment into RMB based on the current exchange rate and dividing it by the total annual GDP. The proportion of employed population in secondary industry (POP_SED) represents the level of industrialization, which is measured by the proportion of people employed in secondary industry to the total employed population. Internal expenditure of R\&D funds $\left(I E \_R D\right)$ represents the technological level. The proportion of public budget expenditure $\left(B U G \_E\right)$ is used to represent fiscal decentralization, which is measured by provincial per capita general public budget expenditure/central per capita general public budget expenditure.

\section{Table 6: Environmental variable substitution and its interpretation or calculation}

\begin{tabular}{l|l|l|c}
\hline $\begin{array}{l}\text { Original } \\
\text { environmental } \\
\text { variable }\end{array}$ & \multicolumn{1}{|c|}{$\begin{array}{c}\text { Environmental variable } \\
\text { substitution }\end{array}$} & $\begin{array}{l}\text { Interpretation or calculation } \\
\text { of environmental variable } \\
\text { substitution }\end{array}$ & Unit \\
\hline IN_EX & $\begin{array}{l}\text { Foreign capital dependence } \\
\left(F_{-} C\right)\end{array}$ & $\begin{array}{l}\text { FDI calculated by converting } \\
\text { it into RMB at current exchange } \\
\text { rate/total annual GDP }\end{array}$ & $\%$ \\
\hline SE_IND & $\begin{array}{l}\text { Proportion of employed } \\
\text { population in secondary } \\
\text { industry }\left(P O P_{-} S E D\right)\end{array}$ & $\begin{array}{l}\text { Employed population } \\
\text { in secondary industry/total } \\
\text { employed population }\end{array}$ & $\%$ \\
\hline $\boldsymbol{R}_{-} \boldsymbol{D}$ & $\begin{array}{l}\text { Internal expenditure of R\&D } \\
\text { funds }\left(I E_{-} R D\right)\end{array}$ & $\begin{array}{l}\text { Annual internal expenditure } \\
\text { of R\&D funds }\end{array}$ & 100 million \\
\hline $\mathbf{L O C} \boldsymbol{F}$ & $\begin{array}{l}\text { Proportion of public budget } \\
\text { expenditure }\left(B U G_{-} E\right)\end{array}$ & $\begin{array}{l}\text { Provincial per capita general } \\
\text { public budget expenditure/ } \\
\text { central per capita general public } \\
\text { budget expenditure }\end{array}$ & $\%$ \\
\hline
\end{tabular}

Source: EPS database, China Statistical Yearbook and China Environmental Statistics Yearbook

In Table 7 , on the basis of $\mathrm{M}_{5}$ (HSFM, Control variable), $\mathrm{M}_{6}-\mathrm{M}_{9}$ replaces one environmental variable successively, and $M_{10}$ replaces all the environmental variables. To be specific, $\mathrm{M}_{6}$ refers to only changing the variable representing economic openness from $I N \_E X$ to $F \_C ; \mathrm{M}_{7}$ refers to only changing the variable representing industrialization level from $S E \_I N D$ to $P O P \_S E D ; \mathrm{M}_{8}$ refers to only changing the variable representing technological level from $R \_D$ to $I E \_R D ; \mathrm{M}_{9}$ refers to only changing the variables representing fiscal decentralization from $L O C_{-} F$ to $B U G_{-} E$, while $\mathrm{M}_{10}$ refers to separately replacing the environmental variables $I N_{-} E X, S E_{-} I N D, R_{-} D$ and $L O C_{-} F$ in $\mathrm{M}_{5}$ with $\mathrm{F}_{-} \mathrm{C}$, 
POP_SED, IE_RD and $B U G_{-} E$. Due to space limitation, only the regression equation part is listed in Table 7 (other relevant estimations are shown in Appendix 3). It can be seen that the coefficients $\operatorname{Ln}\left(C_{-} S\right)$ are significantly positive; the coefficients $\operatorname{Ln}\left(E M_{-} P\right)$ and the $\operatorname{Ln}\left(E N \_C\right)$ are significantly negative; the quadratic term coefficients $\operatorname{Ln}\left(C_{-} S\right) \times \operatorname{Ln}\left(C_{-} S\right)$ are significantly negative; and the interaction term coefficients $\operatorname{Ln}\left(C_{-} S\right) \times \operatorname{Ln}\left(E M_{-} P\right)$ are significantly positive. This is consistent with the basic estimates of $\mathrm{M}_{5}$ in Table 3 .

Table 7: Robustness test results of environmental variables

\begin{tabular}{|c|c|c|c|c|c|}
\hline Model $\left(\mathrm{M}_{\mathrm{i}}\right)$ & $M_{6}$ & $M_{7}$ & $M_{8}$ & $M_{9}$ & $M_{10}$ \\
\hline Estimates & $F_{-} C$ & POP_SED & $I E_{-} R D$ & $B U G_{-} E$ & All \\
\hline $\operatorname{Ln}\left(C_{-} S\right)$ & $\begin{array}{l}6.626^{* * *} \\
(-5.53)\end{array}$ & $\begin{array}{l}5.012^{* * *} \\
(-7.00)\end{array}$ & $\begin{array}{l}5.546^{* * *} \\
(-4.06)\end{array}$ & $\begin{array}{l}4.859 * * * \\
(-6.84)\end{array}$ & $\begin{array}{l}5.153^{* * *} \\
(-7.16)\end{array}$ \\
\hline $\operatorname{Ln}\left(E M \_P\right)$ & $\begin{array}{l}-6.292^{* * *} \\
(-5.62)\end{array}$ & $\begin{array}{l}-6.544^{* * *} \\
(-7.29)\end{array}$ & $\begin{array}{l}-5.345^{* * *} \\
(-4.52)\end{array}$ & $\begin{array}{l}-6.343^{* * *} \\
(-7.14)\end{array}$ & $\begin{array}{l}-6.637^{* * *} \\
(-7.33)\end{array}$ \\
\hline $\operatorname{Ln}\left(E N \_C\right)$ & $\begin{array}{l}-0.367^{* * *} \\
(-4.36)\end{array}$ & $\begin{array}{l}-0.337^{* * *} \\
(-4.25)\end{array}$ & $\begin{array}{l}-0.247^{* * *} \\
(-2.67)\end{array}$ & $\begin{array}{c}-0.354^{* * *} \\
(-4.41)\end{array}$ & $\begin{array}{l}-0.391^{* * *} \\
(-5.03)\end{array}$ \\
\hline $\operatorname{Ln}\left(C \_S\right) \times \operatorname{Ln}\left(C_{-} S\right)$ & $\begin{array}{l}-0.545^{* * *} \\
(-5.89)\end{array}$ & $\begin{array}{l}-0.452^{* * *} \\
(-6.87)\end{array}$ & $\begin{array}{l}-0.462^{* * *} \\
(-4.51)\end{array}$ & $\begin{array}{l}-0.438^{* * *} \\
(-6.70)\end{array}$ & $\begin{array}{c}-0.465^{* * *} \\
(-7.03)\end{array}$ \\
\hline $\operatorname{Ln}\left(C \_S\right) \times \operatorname{Ln}\left(E M{ }_{-} P\right)$ & $\begin{array}{l}0.639 * * * \\
(-6.19)\end{array}$ & $\begin{array}{l}0.621^{* * *} \\
(-7.39)\end{array}$ & $\begin{array}{l}0.549 * * * \\
(-5.03)\end{array}$ & $\begin{array}{l}0.604^{* * *} \\
(-7.25)\end{array}$ & $\begin{array}{l}0.635^{* * *} \\
(-7.50)\end{array}$ \\
\hline $\mathbf{N}$ & 270 & 270 & 270 & 270 & 270 \\
\hline Log likelihood & -192.189 & -165.649 & -203.928 & -163.263 & -171.14 \\
\hline
\end{tabular}

Note: ${ }^{* * *},{ }^{* *}$ and ${ }^{*}$ mean it is significant at the levels of $1 \%, 5 \%$, and $10 \%$, respectively. The $t$ value is in parentheses.

Source: Own analysis

(2) Comparison of green economic efficiency measured using HSFM model and DEA model

Data envelopment analysis (DEA) is a commonly used nonparametric method to measure efficiency. The DEA model used in this paper is from the perspective of input redundancy. Therefore, the authors choose a BCC model with variable input-oriented return to scale, and the input-output indicator is the same as in the HSFM method. A paired sample t-test and a Spearman rank correlation were used to test the measured results. The paired sample t-test results show that the correlation coefficient between the HSFM efficiency value and the DEA efficiency value is 0.732 , and the significance coefficient of linear 
correlation is 0.000 , indicating that there is a strong correlation between the efficiency values calculated by the two methods. At a $95 \%$ confidence level, the confidence interval is $[-0.153,-0.073]$; the paired t-test value is -5.807 ; the degree of freedom is 29 ; and the double-tailed significance probability of the t-test is 0.000 , indicating that the technical efficiency estimated by the HSFM and by the DEA is significantly different.

This difference is mainly due to the fact that the HSFM method takes into account the influence of random factors on the output in the calculation process, and divides the actual output into three parts: production function, statistical noise term and inefficiency term. The DEA method only considers the production frontier and technical inefficiency and does not consider the random error term. That is, the actual output is divided into two parts: production frontier and technical inefficiency.

Figure 2: Comparison of green economic efficiency measurement results by HSFM and by DEA

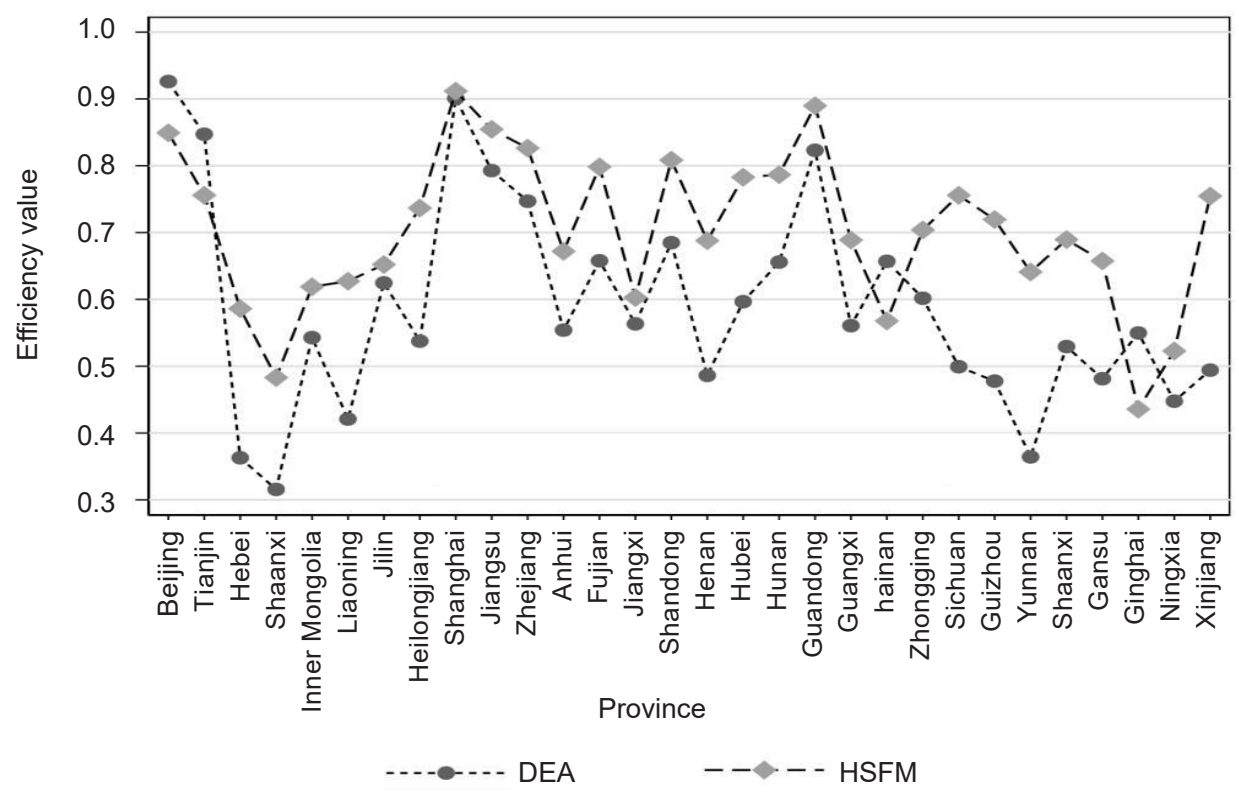

Source: Own analysis

Figure 2 shows a comparison of the mean values of the HSFM and DEA measurement results for each province in the sample period. The HSFM measurement values are generally higher than the DEA measurement values, but on the whole, the two show a similar trend of fluctuation and decline. A Spearman rank correlation test was conducted 
on the green economic efficiency values for the provinces measured by the two methods. The results showed the correlation coefficient was 0.701 and the double-tailed significance probability was 0.000 at the significance level of $5 \%$, indicating that the ranking of the mean value of green economic efficiency for the provinces measured by the HSFM and the DEA had significant consistency. Therefore, the overall ranking of the green economic efficiency values measured by the HSFM and those measured by the DEA is relatively close, so it can be considered that the above calculation results have good reliability.

\subsection{Impact of major environmental factors on inefficiency fluctuations of China's green economy}

\subsubsection{Overall impact on inefficiency fluctuations of China's green economy}

The inefficiency fluctuation of overall green economy estimation based on the HSFM in Table 8 is summarized in Table 3. By comparing the regression results of environmental variables of $\mathrm{M}_{4}$ and $\mathrm{M}_{5}$, it is found that the estimated coefficients of core environmental variables are almost the same, and the significance is greatly improved, which fully indicates that the introduction of control variables is conducive to reducing the endogeneity problem of regression results, and the regression results of $\mathrm{M}_{5}$ are more robust.

It can be seen from the regression results of $\mathrm{M}_{5}$ that the overall impact of various environmental variables on the inefficiency fluctuation of green economy is different. Firstly, the overall impact coefficient of $\operatorname{Ln}\left(I N_{-} E X\right)$ is significantly negative at the $1 \%$ level, indicating that increasing openness can effectively curb inefficiency fluctuations in the green economy. Secondly, the overall influence coefficient of $\operatorname{Ln}\left(S E_{-} I N D\right)$ is significantly negative at the $5 \%$ level, indicating that the industrialization level has a certain inhibitory effect on the green economy inefficiency fluctuations, but the importance is weaker than the openness. Thirdly, the overall influence coefficient of $\operatorname{Ln}\left(R_{-} D\right)$ is significantly negative at the $5 \%$ level, and its absolute value is lower than the industrialization level, indicating that technological level has a certain inhibitory effect on the green economy inefficiency fluctuations, but the importance is weaker than the industrialization level. Fourthly, the overall impact of $\operatorname{Ln}\left(L O C_{-} F\right)$ is not significant, indicating that fiscal decentralization plays a limited role in restraining the inefficiency fluctuations of the green economy. Fifthly, the overall influence coefficient of $R_{-} L O C$ is significantly positive at the $1 \%$ level, indicating that the inefficiency fluctuation of the green economy has an increased trend from the Western to the Central and then to the Eastern regional location. 
Table 8: Inefficiency fluctuation of overall green economy, estimation based on HSFM

\begin{tabular}{|c|c|c|c|c|c|c|c|c|}
\hline \multirow[t]{2}{*}{ Model } & \multirow[t]{2}{*}{ Variable } & \multirow{2}{*}{$\begin{array}{c}\begin{array}{c}\text { Regression } \\
\text { coefficient }\end{array} \\
t \text { value } \\
\end{array}$} & \multirow[t]{2}{*}{ Variable } & \multirow{2}{*}{\begin{tabular}{c|}
$\begin{array}{c}\text { Regression } \\
\text { coefficient }\end{array}$ \\
t value \\
\end{tabular}} & \multirow[t]{2}{*}{ Variable } & \multirow{2}{*}{\begin{tabular}{|c|}
$\begin{array}{c}\text { Regression } \\
\text { coefficient }\end{array}$ \\
t value \\
\end{tabular}} & \multirow{2}{*}{$\begin{array}{l}\text { Control } \\
\text { variable }\end{array}$} & \multirow{2}{*}{\begin{tabular}{|c|}
$\begin{array}{c}\text { Regression } \\
\text { coefficient }\end{array}$ \\
t value \\
\end{tabular}} \\
\hline & & & & & & & & \\
\hline \multirow{2}{*}{ M4: HSFM } & $\operatorname{Ln}\left(I N \_E X\right)$ & $\begin{array}{l}-0.727^{* * *} \\
(-4.54)\end{array}$ & $\operatorname{Ln}\left(R_{-} D\right)$ & $\begin{array}{l}-0.186^{*} \\
(-2.29)\end{array}$ & $R_{-} L O C$ & $\begin{array}{l}0.307^{* *} \\
(-2.67)\end{array}$ & - & $\begin{array}{l}- \\
- \\
-\end{array}$ \\
\hline & $\operatorname{Ln}\left(S E_{-} I N D\right)$ & $\begin{array}{l}-0.849^{*} \\
(-2.17)\end{array}$ & $\operatorname{Ln}\left(L O C_{-} F\right)$ & $\begin{array}{c}0.096 \\
(-0.28)\end{array}$ & - & - & - & - \\
\hline \multirow{2}{*}{$\begin{array}{l}\text { M5: HSFM } \\
\text { (Control } \\
\text { variable) }\end{array}$} & $\operatorname{Ln}\left(I N \_E X\right)$ & $\begin{array}{l}-0.501^{* * *} \\
(-3.16)\end{array}$ & $\operatorname{Ln}\left(R_{-} D\right)$ & $\begin{array}{l}-0.176^{* *} \\
(-1.96)\end{array}$ & $R_{-} L O C$ & $\begin{array}{l}3.913^{* * *} \\
(-4.03)\end{array}$ & $\operatorname{Ln}\left(F A \_G D P\right)$ & $\begin{array}{l}-0.216^{*} \\
(-1.94)\end{array}$ \\
\hline & $\operatorname{Ln}\left(S E_{-} I N D\right)$ & $\begin{array}{l}-0.946^{* *} \\
(-2.20)\end{array}$ & $\operatorname{Ln}\left(L O C_{-} F\right)$ & $\begin{array}{l}-0.042 \\
(-0.11)\end{array}$ & - & - & $\operatorname{Ln}\left(C_{-} E N\right)$ & $\begin{array}{l}0.529^{*} \\
(-1.80)\end{array}$ \\
\hline
\end{tabular}

Note: ${ }^{* *},{ }^{* *}$ and ${ }^{*}$ mean it is significant at the $1 \%, 5 \%$, and $10 \%$ levels, respectively. The $t$ value is in parentheses.

Source: Own analysis

\subsubsection{Impact on inefficiency fluctuations of China's regional green economy}

Table 9 is the result of green economy inefficiency fluctuation estimated by $M_{5}$ based on the data of three regions in China. It can be seen from Table 9 that the influences of $\operatorname{Ln}\left(I N \_E X\right)$ are all negative and significant at the $1 \%$ level. From the absolute value of $\operatorname{Ln}\left(I N \_E X\right)$, Eastern region $>$ Western region $>$ Central region, which indicates that the inhibition degree of openness on the inefficiency fluctuations of the green economy in the Central and Western regions is weaker than that in the Eastern region. The impact of $\operatorname{Ln}\left(S E_{-} I N D\right)$ in the Eastern region is -1.860 , which is significant at the $5 \%$ level, indicating that the level of industrialization can significantly inhibit the green economy inefficiency fluctuations in the Eastern region; the impact of $\operatorname{Ln}\left(S E_{-} I N D\right)$ level in the Central and Western regions are 0.734 and 0.115 respectively, which are not significant, indicating that the level of industrialization does not significantly increase the inefficiency fluctuations of the green economy in the Central and Western regions. The influences of $\operatorname{Ln}\left(R_{-} D\right)$ in the Central and Western regions are -0.907 and -0.287 respectively, which are significant at the $5 \%$ and $10 \%$ level respectively, indicating that technological level has a certain inhibitory effect on the inefficiency fluctuations of the green economy in the Central and Western regions, but the influence is lower than that of openness. The influence of $\operatorname{Ln}\left(R_{-} D\right)$ in the Eastern region is 0.435 , it is significant at the $10 \%$ level, which indicates that the technological level of the Eastern region has a certain aggravating effect on the fluctuation of inefficiency. In terms of the influence 
of $\operatorname{Ln}\left(L O C_{-} F\right)$, they are $1.967,1.304$, and -1.221 in the Eastern, Western, and Central regions respectively, and they are all insignificant, indicating that the influence of fiscal decentralization is not obvious in the three major regions of China.

Table 9: Inefficiency fluctuation of regional green economy, estimation based on $M_{5}$

\begin{tabular}{|c|c|c|c|}
\hline \multirow[b]{2}{*}{ Variable } & Regression coefficient & Regression coefficient & Regression coefficient \\
\hline & $\begin{array}{c}\text { t value } \\
\text { Western region }\end{array}$ & $\begin{array}{c}\text { t value } \\
\text { Central region }\end{array}$ & $\begin{array}{c}\text { t value } \\
\text { Eastern region }\end{array}$ \\
\hline $\operatorname{Ln}\left(I N \_E X\right)$ & $\begin{array}{l}-1.493^{* * *} \\
(-4.39)\end{array}$ & $\begin{array}{l}-1.180^{* * *} \\
(-2.89)\end{array}$ & $\begin{array}{l}-3.854^{* * *} \\
(-5.14)\end{array}$ \\
\hline $\operatorname{Ln}\left(S E \_I N D\right)$ & $\begin{array}{c}0.115 \\
(-0.29)\end{array}$ & $\begin{array}{c}0.734 \\
(-0.94)\end{array}$ & $\begin{array}{c}-1.860^{* *} \\
(-2.42)\end{array}$ \\
\hline $\operatorname{Ln}\left(R \_D\right)$ & $\begin{array}{l}-0.287^{*} \\
(-1.85)\end{array}$ & $\begin{array}{l}-0.907^{* *} \\
(-2.38)\end{array}$ & $\begin{array}{l}0.435^{*} \\
(-1.83)\end{array}$ \\
\hline $\operatorname{Ln}\left(L O C_{-} F\right)$ & $\begin{array}{l}1.304 \\
(-1.59)\end{array}$ & $\begin{array}{l}-1.221 \\
(-1.13)\end{array}$ & $\begin{array}{c}1.967 \\
(-1.48)\end{array}$ \\
\hline
\end{tabular}

Note: ${ }^{* * *},{ }^{* *}$ and ${ }^{*}$ mean it is significant at the $1 \%, 5 \%$, and $10 \%$ levels, respectively. The $t$ value is in parentheses.

Source: Own analysis

\subsection{Impact on marginal utility of inefficiency fluctuations in China's green economy}

For $\mathrm{M}_{5}$, the fiscal decentralization variables with insignificant effects are removed from the affecting variables, and then the marginal utility of other affecting variables on the inefficiency fluctuations of the green economy is calculated according to Formula (10). The specific results are shown in Figure 3.

\section{(1) Overall perspective}

The marginal utility of $\operatorname{Ln}\left(I N \_E X\right), \operatorname{Ln}\left(S E \_I N D\right)$, and $\operatorname{Ln}\left(R \_D\right)$ on the inefficiency fluctuations of the green economy are $-0.308,-0.064$, and -0.053 , respectively, indicating that unit change in openness can inhibit China's green economy inefficiency fluctuations relatively obviously; unit change in industrialization level and technology level can also play a certain role in restraining the inefficiency of China's green economy. In terms of time, unit change in openness and industrialization level has shown a restraining trend from strong to weaker to stronger inefficiency fluctuations in China's green economy; unit change in technology level has shown a relatively stable inhibitory effect on the inefficiency fluctuations of China's green economy. 
(2) Perspective of concrete impact

In terms of the impact of openness on marginal utility of inefficiency fluctuation of China's regional green economy, unit change in openness has a much more restraining effect on the inefficiency fluctuation of the green economy in the Central region than in the Western and Eastern regions. The marginal utility changes relatively smoothly in the Eastern region, while the Central and Western regions show an "inverted U-shape", indicating that the change in openness has a relatively small and stable inhibitory effect on the green economy inefficiency fluctuations in the Eastern region, and its suppression in the Central and Western regions shows a trend from strong to weak and then to stronger.

Figure 3: Impact of openness, industrialization level, technological level on marginal utility of inefficiency fluctuations in China's regional green economy

(a) Openness level

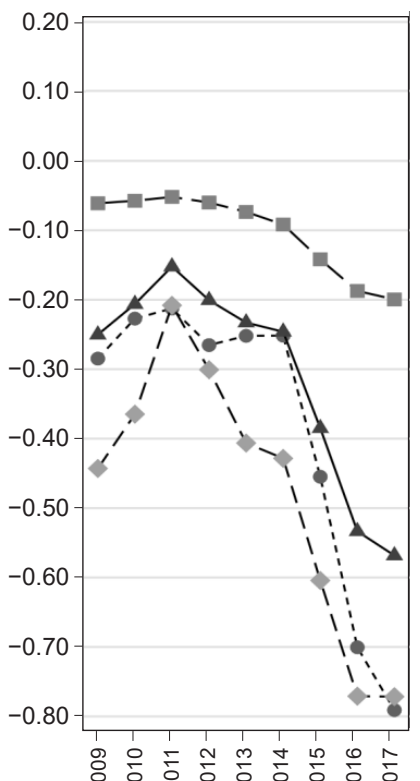

융 융

--•-. Western (b) Industrialization level

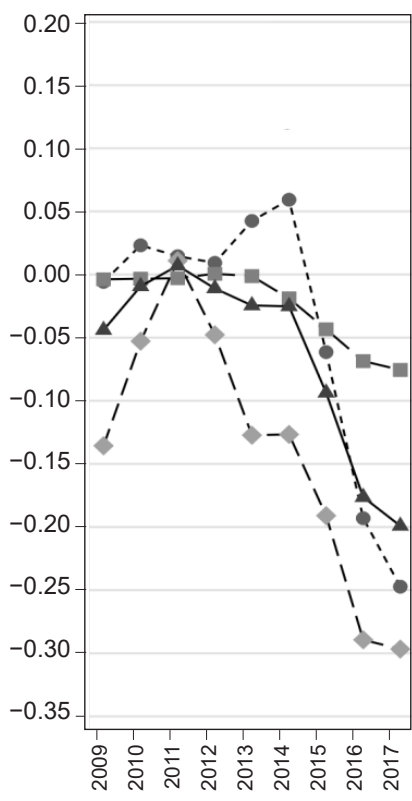

$\rightarrow$ - Eastern (c) Technical level

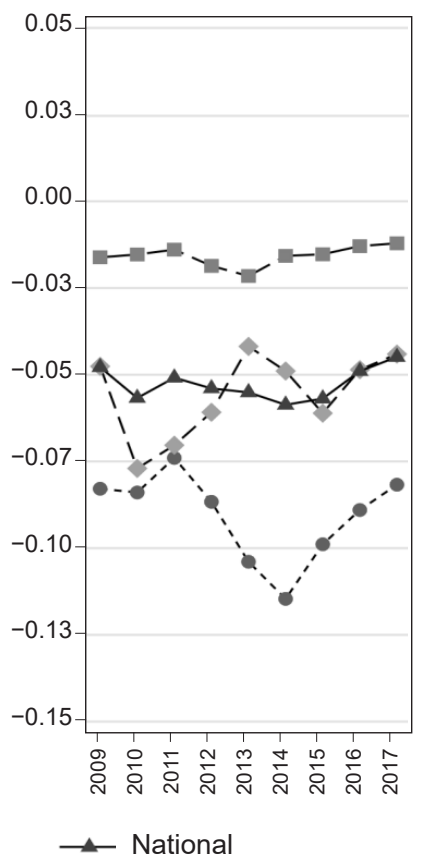

Source: Own analysis

In terms of the impact of industrialization level on marginal utility of inefficiency fluctuation of China's regional green economy, the inhibitory effect of unit changes in industrialization level on the inefficiency fluctuation of green economic in the Central region is greater than that in the Eastern region; and the inhibitory effect in both Central 
and Eastern regions shows a trend from strong to weak and then to stronger. Since 2015, unit change in industrialization level has had a rapidly increasing restraining effect on the inefficiency fluctuation of the Western region's green economy, and unit change in industrialization level has had a stronger inhibitory effect on the inefficiency fluctuation of green economy in the Central and Western regions than in the Eastern region.

In terms of the impact of technological level on marginal utility of inefficiency fluctuation of China's regional green economy, unit change in technology level has a more restraining effect on the inefficiency fluctuations of the green economy in the Western region than in the Central and Eastern regions. Since 2015, the inhibitory effect of unit change in technological level in the Western, Central and Eastern regions on the inefficiency fluctuation of regional green economy has shown a trend from strong to weak.

\section{Conclusions and Policy Recommendations}

\subsection{Research conclusions}

Firstly, China's overall green economy efficiency average is low, and the regional heterogeneity of green economy efficiency is obvious. Except for a few years, the average green economy efficiency of the Eastern region has been higher than that of the Central and Western regions. The provinces with high average green economy efficiency are mainly concentrated in the Southeast coastal area, and form the Beijing-Shandong-JiangsuZhejiang-Shanghai-Guangdong contiguous distribution belt. Most of the provinces with low average green economy efficiency have a resource-based economic growth pattern.

Secondly, for China's green economy inefficiency, openness has a significant inhibitory effect on the overall inefficiency fluctuation of the green economy; industrialization level and technological level have a certain inhibitory effect, but their importance is weaker than that of openness; fiscal decentralization has an insignificant effect. For the inefficiency fluctuations of the green economy, since 2001, unit changes in openness and industrialization level have had a strengthened restraining effect on the inefficiency fluctuations of China's green economy, and unit change in technology level has had a small and stable inhibitory effect on China's green economy's inefficiency fluctuation.

Lastly, for the inefficiency fluctuations of green economy in China's different regions, openness restrains the Eastern region to a greater degree than it does the Central and Western regions; and industrialization level has a significant inhibitory effect on the Eastern region, but it has little effect on the Central and Western regions; technological level has a certain inhibitory effect on the Central and Western regions, but its influence is lower than that of openness. The inhibitory effect of unit change in openness and industrialization level on the inefficiency fluctuation of green economy in the Central region is greater than 
that in the Eastern region. The inhibitory effect of unit change in technological level on the inefficiency fluctuation of green economy in the Western region is obviously greater than that in the Central and Eastern regions. In recent years, unit change in openness and industrialization level has enhanced inhibition on green economy inefficiency fluctuation in three areas. However, the inhibitory effect of unit change in technological level on the inefficiency fluctuation of regional green economy has a weakening trend.

\subsection{Policy countermeasures and suggestions}

Firstly, governments at all levels should actively play the role of opening up industrial structure and innovation capabilities in regulating the development of the green economy, such as steadily improving the level of opening up, actively carrying out the optimization and upgrading of internal industrial structure and the transfer of external industrial structure, and continuously accelerating the invention, communication and sharing of green core technologies. At the same time, it is necessary to further clarify the financial powers of the central and local governments, and actively establish a fiscal decentralization incentive mechanism which has clear powers and responsibilities, financial coordination and regional balance. It is desired to help restrain the inefficiency fluctuations of the green economy.

Secondly, to maintain sustained and stable growth of the green economy, the Central and Western regions should promote economic opening and industrialization level, and the Western region should still pay attention to technology innovation in green productivity growth. Meanwhile, the local economic foundation, industry type and resource endow- ment should be combined to actively promote the stable transferring of local low-end manufacturing to high-tech industries and emerging industries in the Central and Western regions. The Eastern region should further improve the quality of opening up, vigorously develop modern service industries and advanced manufacturing, and continuously promote the optimization and upgrading of the regional industrial structure and high-quality economic development.

Lastly, it is necessary to guide the rational flow of various elements and resources among different regions, and continuously encourage regions to optimize their environmental factors and to gradually narrow the regional gap of green economy development environment and green economy development efficiency. All regions should also take into account regional realities, adapt measures to local conditions, maximize their strengths and avoid weaknesses, give full play to their own element advantages or location advantages, continuously seek opportunities in economic development power, industrial structure and other aspects, actively create a good environment conducive to promoting regional green economy development, and constantly enhance the strength of their own green economy development. 
Appendix 1: Statistical results of output variables

\begin{tabular}{|c|c|c|c|c|c|c|}
\hline \multirow{2}{*}{ Province } & \multicolumn{2}{|c|}{ Desired output (R_GDP) } & \multicolumn{2}{|c|}{ Undesired output (IND_W) } & \multicolumn{2}{|c|}{ Comprehensive output } \\
\hline & Mean & Std. dev. & Mean & Std. dev. & Mean & Std. dev. \\
\hline Shanghai & $21,596.470$ & $4,845.4579$ & $2,055.7189$ & 303.6406 & 0.64423955 & 0.22709344 \\
\hline Yunnan & $11,135.324$ & $3,490.7306$ & $13,657.1220$ & $2,938.5818$ & 0.36521187 & 0.16943782 \\
\hline $\begin{array}{l}\text { Inner } \\
\text { Mongolia }\end{array}$ & $14,988.669$ & $2,889.6726$ & $22,174.3610$ & $5,000.4731$ & 0.31439583 & 0.08740214 \\
\hline Beijing & $19,044.542$ & $5,104.3592$ & 975.0415 & 253.1792 & 0.61592918 & 0.25817461 \\
\hline Jilin & $11,886.357$ & $2,769.3904$ & $4,751.3277$ & 528.7091 & 0.47916286 & 0.25333520 \\
\hline Sichuan & $25,309.724$ & $7,425.5102$ & $12,421.9580$ & $1,758.8666$ & 0.56169013 & 0.11602119 \\
\hline Tianjin & $13,336.783$ & $3,740.2996$ & $1,645.3430$ & 147.0355 & 0.53151765 & 0.28635187 \\
\hline Ningxia & $2,442.850$ & 690.0227 & $3,229.3383$ & 945.1654 & 0.36659986 & 0.31936057 \\
\hline Anhui & $18,218.261$ & $5,548.4287$ & $11,419.4170$ & $1,554.3351$ & 0.47882903 & 0.15076748 \\
\hline Shandong & $52,936.884$ & $12,968.5580$ & $19,072.9200$ & $2,979.5566$ & 0.85692281 & 0.23535145 \\
\hline Shanxi & $11,507.662$ & $2,232.6276$ & $27,235.6210$ & $6,429.3994$ & 0.20197051 & 0.09301451 \\
\hline Guangdong & $60,471.638$ & $15,630.5410$ & $5,682.9982$ & 438.9736 & 1.10940070 & 0.13741515 \\
\hline Guangxi & $13,590.314$ & $3,957.5684$ & $7,050.9638$ & 804.6466 & 0.47435659 & 0.23070320 \\
\hline Xinjiang & $7,783.499$ & $2,171.9159$ & $6,923.1107$ & $2,263.8134$ & 0.39242121 & 0.24437227 \\
\hline Jiangsu & $58,019.796$ & $16,492.3470$ & $10,436.0410$ & 1,231.7497 & 1.01161490 & 0.16511531 \\
\hline Jiangxi & $13,796.966$ & $4,144.5485$ & $10,992.6530$ & $1,226.4217$ & 0.43027383 & 0.18101471 \\
\hline Hebei & $26,389.669$ & $5,667.7056$ & $36,768.2290$ & $7,842.4434$ & 0.33551017 & 0.15817722 \\
\hline Henan & $31,199.196$ & $8,132.1376$ & $14,241.5460$ & $2,084.2049$ & 0.62307703 & 0.08225176 \\
\hline Zhejiang & $36,112.255$ & $8,874.4013$ & $4,351.1206$ & 195.5462 & 0.80625187 & 0.13535606 \\
\hline Hainan & $3,002.426$ & 900.9046 & 371.0541 & 105.0826 & 0.40902181 & 0.35698346 \\
\hline Hubei & $23,966.710$ & $7,623.1166$ & $7,535.9727$ & 857.1213 & 0.59652873 & 0.16925435 \\
\hline Hunan & $23,586.732$ & $7,048.1466$ & $6,556.4226$ & $1,471.4400$ & 0.61055260 & 0.19307781 \\
\hline Gansu & $5,814.562$ & $1,480.8720$ & $5,376.3498$ & $1,212.4087$ & 0.39117092 & 0.28476382 \\
\hline Fujian & $21,084.813$ & $6,384.0349$ & $6,023.0221$ & $1,555.9081$ & 0.58214594 & 0.20730998 \\
\hline Guizhou & $7,979.335$ & $3,237.1201$ & $7,854.2408$ & 678.9575 & 0.38376950 & 0.25220758 \\
\hline Liaoning & $22,990.908$ & $4,463.8694$ & $25,354.5330$ & $5,215.3120$ & 0.38933620 & 0.15853410 \\
\hline Chongqing & $12,408.824$ & $4,264.6622$ & $2,794.1456$ & 441.1268 & 0.50240464 & 0.28576003 \\
\hline Shaanxi & $15,112.248$ & $4,498.9790$ & $7,889.2882$ & $1,404.1618$ & 0.47478636 & 0.19506923 \\
\hline Qinghai & $1,995.245$ & 564.3830 & $10,531.4300$ & $5,186.5856$ & 0.26903497 & 0.21078314 \\
\hline $\begin{array}{l}\text { Heilong- } \\
\text { jiang }\end{array}$ & $13,209.503$ & $2,540.5243$ & $6,324.5197$ & 741.6241 & 0.48167367 & 0.22265393 \\
\hline Total & $20,030.605$ & $16,093.3120$ & $10,056.5270$ & $8,778.7902$ & 0.52299336 & 0.28563543 \\
\hline
\end{tabular}

Source: EPS database, China Statistical Yearbook and China Environmental Statistics Yearbook 
Appendix 2: Green economic efficiency of sample provinces (2009-2017)

\begin{tabular}{|c|c|c|c|c|c|c|c|c|c|c|}
\hline Province & 2009 & 2010 & 2011 & 2012 & 2013 & 2014 & 2015 & 2016 & 2017 & Mean \\
\hline nai & 0.920 & 0.929 & 0.918 & 0.942 & 0.934 & 0.928 & 0.944 & 0.752 & 0.939 & 0.912 \\
\hline Yunnan & 58 & 538 & 0.520 & 789 & 726 & 680 & 814 & .248 & 797 & 641 \\
\hline ner $M$ & 0.601 & 0.652 & 0.648 & 0.789 & 0.766 & 0.719 & 0.506 & 0.428 & 0.459 & 0.619 \\
\hline ijing & 0.876 & 0.883 & 0.850 & 0.914 & 0.898 & 0.883 & 0.922 & 0.506 & 0.911 & 0.849 \\
\hline Jilin & 0.498 & 0.567 & 0.518 & 0.805 & 0.765 & 0.725 & 0.875 & 0.239 & 0.877 & 0.652 \\
\hline chuan & 0.717 & 0.773 & 0.780 & 0.866 & 0.802 & 0.778 & 0.775 & 0.526 & 0.786 & 0.756 \\
\hline anjin & 0.666 & 0.722 & 0.676 & 0.876 & 0.857 & 0.834 & 0.915 & 0.342 & 0.915 & 0.756 \\
\hline 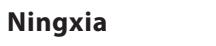 & 0.345 & 0.388 & 0.250 & 717 & 0.661 & 0.564 & 0.890 & .018 & 0.872 & 0.523 \\
\hline inhui & 0.530 & 0.617 & 0.588 & 0.789 & 0.746 & 0.722 & 0.795 & 0.420 & 0.840 & 0.672 \\
\hline Ian & 0.893 & 0.899 & 0.890 & 0.900 & 0.865 & 0.865 & 0.528 & 0.833 & 0.604 & 0.808 \\
\hline hanxi & 546 & 0 & 0 & 9 & 6 & 3 & 36 & 43 & 058 & 483 \\
\hline Guangdon & 0.946 & 0.945 & 0.943 & 0.944 & 0.918 & 0.904 & 0.793 & 0.821 & 0.794 & 0.890 \\
\hline Jangxi & 0 & 0 & 0 & 13 & 6 & 25 & 1 & 308 & 4 & 689 \\
\hline injiang & 0.772 & 0.811 & 0.695 & 0.882 & 0.842 & 0.795 & 0.910 & 0.191 & 0.893 & 0.755 \\
\hline angsu & 0.924 & 0.928 & 0.927 & 0.934 & 0.875 & 0.853 & 0.662 & 0.811 & 0.777 & 0.855 \\
\hline nqui & 0.430 & 0 & 0 & 0.745 & 2 & 8 & 0 & 3 & 5 & 3 \\
\hline ebei & 0.761 & 0.772 & 0.786 & 0.717 & 0.671 & 0.648 & 0.005 & 0.653 & 0.263 & 0.586 \\
\hline An & 0.135 & 3 & 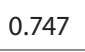 & 0 & 9 & 2 & 588 & 482 & 625 & 0.688 \\
\hline hejiang & 0.863 & 0.877 & 0.853 & 0.875 & 0.857 & 0.825 & 0.817 & 0.626 & 0.843 & 0.826 \\
\hline lainan & 0.451 & 0.526 & 0.331 & 0.774 & 0.692 & 0.575 & 0.881 & 0.029 & 0.849 & 0.568 \\
\hline ubei & 0.100 & 0.820 & 0.101 & 0.869 & 0.014 & 0.789 & 0.829 & 0.503 & 0.848 & 0.783 \\
\hline unan & 0.767 & 0.802 & 0.759 & 0.856 & 0.816 & 0.801 & 0.851 & 0.537 & 0.891 & 0.787 \\
\hline iansu & 0.615 & 0.673 & 0.470 & 0.817 & 0.780 & 0.687 & 0.893 & 0.103 & 0.880 & 0.658 \\
\hline iian & 213 & 0 & 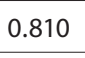 & 374 & 0.838 & 818 & 0.870 & 0.459 & 0.864 & 0.798 \\
\hline Guizhou & 0.689 & 0.743 & 0.612 & 0.874 & 0.822 & 0.765 & 0.901 & 0.206 & 0.864 & 0.720 \\
\hline ing & 0. & 0. & 0. & 0. & 6 & 0 & 3 & 2 & 0.476 & 0.627 \\
\hline Chongqing & 0.554 & 0.633 & 0.603 & 0.856 & 0.814 & 0.775 & 0.898 & 0.304 & 0.899 & 0.704 \\
\hline Shaanxi & 0.610 & 0.671 & 0.608 & 0.815 & 0.767 & 0.725 & 0.842 & 0.324 & 0.843 & 0.690 \\
\hline nai & 0. & 0.428 & 0.220 & 2 & 0.499 & 30 & 0.723 & 0.004 & 0.686 & 0.436 \\
\hline Heilongjiang & 0.740 & 0.773 & 0.710 & 0.850 & 0.796 & 0.756 & 0.872 & 0.263 & 0.870 & 0.737 \\
\hline Total & 0.679 & 0.726 & 0.667 & 0.829 & 0.779 & 0.737 & 0.744 & 0.398 & 0.763 & 0.702 \\
\hline
\end{tabular}

Source: Own analysis 
Appendix 3: Robustness test results of environmental variables (regression equation results are shown in Table 7)

\begin{tabular}{|c|c|c|c|c|c|c|}
\hline \multirow{2}{*}{ Model $\left(M_{i}\right)$} & $M_{5}:$ HSFM & $M_{6}$ & $M_{7}$ & $M_{8}$ & $M_{9}$ & $M_{10}$ \\
\hline & (Control variable) & $F_{-} C$ & POP_SED & $I E_{-} R D$ & BUG_E & All \\
\hline \multicolumn{7}{|c|}{ Fluctuation of random error term $\left(\ln \sigma_{v}^{2}\right)$} \\
\hline _cons & $\begin{array}{l}-2.785^{* * *} \\
(-14.81)\end{array}$ & $\begin{array}{l}10.396^{* * *} \\
(-3.32)\end{array}$ & $\begin{array}{c}-136.136 \\
(-0.91)\end{array}$ & $\begin{array}{l}9.295^{* *} \\
(-2.49)\end{array}$ & $\begin{array}{c}-103.25 \\
(-1.06)\end{array}$ & $\begin{array}{c}-187.812 \\
(-0.84) \\
\end{array}$ \\
\hline
\end{tabular}

Fluctuation of inefficiency term $\left(\ln \sigma_{u, i t}^{2}\right)$

\begin{tabular}{|c|c|c|c|c|c|c|}
\hline $\operatorname{Ln}\left(I N \_E X\right)$ & $\begin{array}{c}-0.501^{* * *} \\
(-3.16)\end{array}$ & - & $\begin{array}{c}-0.455^{* * *} \\
(-2.88)\end{array}$ & $\begin{array}{l}-1.810^{* * *} \\
(-4.46)\end{array}$ & $\begin{array}{c}-0.504^{* * *} \\
(-3.67)\end{array}$ & - \\
\hline $\operatorname{Ln}\left(S E_{-} I N D\right)$ & $\begin{array}{l}-0.946^{* *} \\
(-2.20)\end{array}$ & $\begin{array}{l}-3.994^{* * *} \\
(-3.04)\end{array}$ & - & $\begin{array}{l}-4.766^{* * *} \\
(-4.48)\end{array}$ & $\begin{array}{l}-1.012^{* *} \\
(-2.30)\end{array}$ & - \\
\hline $\operatorname{Ln}\left(R \_D\right)$ & $\begin{array}{l}-0.176^{* *} \\
(-1.96)\end{array}$ & $\begin{array}{c}-0.599 * * \\
(-2.01)\end{array}$ & $\begin{array}{l}-0.182^{* *} \\
(-1.99)\end{array}$ & - & $\begin{array}{c}-0.210^{* *} \\
(-2.18)\end{array}$ & - \\
\hline $\ln \left(L O C_{-} F\right)$ & $\begin{array}{l}-0.042 \\
(-0.11)\end{array}$ & $\begin{array}{c}-5.838^{* * *} \\
(-3.38)\end{array}$ & $\begin{array}{l}-0.002 \\
(-0.01)\end{array}$ & $\begin{array}{l}-0.085 \\
(-0.11)\end{array}$ & $\begin{array}{l}- \\
-\end{array}$ & - \\
\hline Local & $\begin{array}{l}3.913^{* * *} \\
(-4.03)\end{array}$ & $\begin{array}{l}4.661^{* *} \\
(-2.19)\end{array}$ & $\begin{array}{l}2.098^{* * *} \\
(-2.79)\end{array}$ & $\begin{array}{c}3.271^{* *} \\
(-2.09)\end{array}$ & $\begin{array}{l}3.737^{* * *} \\
(-3.74)\end{array}$ & $\begin{array}{l}3.240^{* * *} \\
(-3.40)\end{array}$ \\
\hline $\operatorname{Ln}\left(C C_{-} E N\right)$ & $\begin{array}{l}0.529^{*} \\
(-1.80)\end{array}$ & $\begin{array}{l}15.983^{* * *} \\
(-5.69)\end{array}$ & $\begin{array}{c}0.459 \\
(-1.60)\end{array}$ & $\begin{array}{l}2.287^{* * *} \\
(-4.55)\end{array}$ & $\begin{array}{l}0.553^{*} \\
(-1.84)\end{array}$ & $\begin{array}{l}0.769 * * * \\
(-2.99)\end{array}$ \\
\hline $\operatorname{Ln}\left(F A \_G D P\right)$ & $\begin{array}{l}-0.216^{*} \\
(-1.94)\end{array}$ & $\begin{array}{c}-1.348^{* * *} \\
(-3.50)\end{array}$ & $\begin{array}{l}-0.217^{* *} \\
(-2.00)\end{array}$ & $\begin{array}{l}-1.278^{* * *} \\
(-4.55)\end{array}$ & $\begin{array}{c}-0.260^{* *} \\
(-2.23)\end{array}$ & $\begin{array}{c}-0.193 * \\
(-1.71)\end{array}$ \\
\hline $\ln \left(F_{-} C\right)$ & - & $\begin{array}{l}0.776^{* *} \\
(-2.06)\end{array}$ & - & $\begin{array}{l}- \\
-\end{array}$ & $\begin{array}{l}- \\
-\end{array}$ & $\begin{array}{l}-0.077 \\
(-0.78)\end{array}$ \\
\hline $\ln \left(P O P \_S E D\right)$ & - & - & $\begin{array}{l}-0.404 \\
(-1.12) \\
\end{array}$ & - & - & $\begin{array}{l}-0.394 \\
(-1.03)\end{array}$ \\
\hline $\ln \left(I E \_R D\right)$ & - & - & - & $\begin{array}{l}0.318^{* *} \\
(-2.15)\end{array}$ & - & $\begin{array}{c}-0.233^{* *} \\
(-2.42)\end{array}$ \\
\hline $\ln \left(B \cup G \_E\right)$ & $\begin{array}{l}- \\
-\end{array}$ & - & - & - & $\begin{array}{l}-0.254 \\
(-1.00)\end{array}$ & $\begin{array}{c}-0.3 \\
(-1.26)\end{array}$ \\
\hline
\end{tabular}

Mean of inefficiency terms $\left(\ln w_{u, i t}\right)$

\begin{tabular}{l|c|c|c|c|c|c}
\hline cons & $\begin{array}{c}-187.812 \\
(-0.84)\end{array}$ & $\begin{array}{c}-1.963^{* * *} \\
(-18.88)\end{array}$ & $\begin{array}{c}-2.802^{* * *} \\
(-14.45)\end{array}$ & $\begin{array}{l}-2.694^{* * *} \\
(-10.23)\end{array}$ & $\begin{array}{c}-2.769^{* * *} \\
(-14.69)\end{array}$ & $\begin{array}{c}-2.834^{* * *} \\
(-14.04)\end{array}$ \\
\hline $\mathbf{N}$ & 270 & 270 & 270 & 270 & 270 & 270 \\
\hline Log likelihood & -163.743 & -192.189 & -165.649 & -203.928 & -163.263 & -171.14 \\
\hline
\end{tabular}

Source: Own analysis 


\section{References}

Abdullah, H., Bakar, N. A., Jali, M. R. M., et al. (2017). The Current State of Malaysia's Journey towards a Green Economy: The Perceptions of the Companies on Environmental Efficiency and Sustainability. International Journal of Energy Economics and Policy, 7(1), 253-258. Available at: https://ideas.repec.org/a/eco/journ2/2017-04-28.html

Bi, X., Liu, P. (2019). Research on the Influence of Environmental Regulation on the Efficiency of Green Economy in China[J]. IOP Conference Series Earth and Environmental Science, 252, 042014, https://doi.org/10.1088/1755-1315/252/4/042014

Bleischwitz, R., Yong, G., Walz, R., et al. (2018). Euro-China Green Economy theme: SINCERE (Sino-European Circular Economy and Resource Efficiency) - ESRC. Impact, 4, 6-7, https://doi.org/10.21820/23987073.2018.4.6

Chen, J., Wang, L. J., Li, Y. Y. (2020). Research on the Impact of Multi-dimensional Urbanization on China's Carbon Emissions under the Background of COP21. Journal of Environmental Management, 273, 111-123, https://doi.org/10.1016/j.jenvman.2020.111123

Chen, S., Golley, J. (2014). "Green" Productivity growth in China's Industrial Economy. Energy Economics, 44, 89-98, https://doi.org/10.1016/j.eneco.2014.04.002

Feng, J., Zhang, S. Q. (2017). Evaluation of China's Provincial Green Total Factor Productivity Based on DEA Method: Analysis on the Difference of Different Model Selection. Acta Scientiarum Naturalium Universitatis Pekinensis, 53(01), 151-159, https://doi.org/10.1320 9/j.0479-8023.2016.119

Guermat, C., Hadri, K. (1999). Heteroscedasticity in Stochastic Frontier Models: A Monte-Carlo Analysis. University of Exeter, Department of Economics. Discussion Papers No. 9914. Available at: https://ideas.repec.org/p/exe/wpaper/9914.html

Hall, R. E., Jones, C. I. (1999). Why Do Some Countries Produce So Much More Output per Worker than Others? Stanford University. Stanford, CA Working Paper No. 98-007, https://doi.org/10.2139/ssrn.3595

Hu, A. J., Guo, A. J., Zhong, F. L., et al. (2018). Can High-tech Industrial Agglomeration Improve Regional Green Economy Efficiency? China Population, Resources and Environment, 28(09), 93-101, https://doi.org/10.12062/cpre.20180404

Hu, Z. Y., Li, Y., Liu, Y. W. (2017). Research on Regional Differences and Convergence of Green Technology Efficiency in China. Soft Science, 31(08), 1-4, https://doi.org/10.13956/j. ss.1001-8409.2017.08.01

Huber, P. J. (1985). Projection pursuit. Ann Statist, 13(02): 435-475, DOI: 10.1214/aos/ 1176349519

Kasayanond, A., Umam, R., Jermsittiparsert, K. (2019). Environmental Sustainability and its Growth in Malaysia by Elaborating the Green Economy and Environmental Efficiency. International Journal of Energy Economics and Policy, 9(5), 465-473, https://doi.org/10.32479/ijeep.8310 
Krivorotov, V., Kalina, A., Savelyeva, A., et al. (2018). Methodological Tools for Energy Efficiency Assessment of Industrial Systems in a Context of Transition to a "Green Economy". Challenges and Solutions in the Russian Energy Sector, 19-26, https://doi.org/10.2495/978-1-78466-175-5/003

Li, L. H., Yue, Y. F. (2019). Evaluation of Green Development Efficiency in China Based on Fourstage DEA Model. Science and Technology Management Research, 39(24), 247-258, https://doi.org/10.3969/j.issn.1000-7695.2019.24.033

Lin, B. Q., Tan, R. P. (2019). Economic Agglomeration and Green Economic Efficiency in China. Economic Research Journal, 54(02), 119-132. Available at: http://www.wanfangdata.com. cn/details/detail.do?_type=perio\&id=jjyj201902008

Liu, Y. B., Yuan, H. X., Wang, Z. (2017). The Impact of Cultural Industry Agglomeration on Green Economy Efficiency: An Empirical Analysis Based on Dynamic Panel Model. Resources Science, 39(04), 747-755, https://doi.org/10.18402/resci.2017.04.15

Matraeva, L. V., Goryunova, N. A., Smirnova, S. N., et al. (2017). Methodological Approaches to Estimation of Energy Efficiency within the Framework of the Concept of Green Economy and Sustainable Development. International Journal of Energy Economics \& Policy, 7(4), 231-239. Available at: https://ideas.repec.org/a/eco/journ2/2017-04-28.html

Qian, Z. M., Liu, X. C. (2015). Environmental Regulation and Green Economic Efficiency. Statistical Research, 32(07), 12-18, https://doi.org/10.19343/j.cnki.11-1302/c.2015.07.002

Shuai, S., Fan, Z. (2020). Modeling the Role of Environmental Regulations in Regional Green Economy Efficiency of China: Empirical Evidence from Super Efficiency DEA-Tobit Model. Journal of Environmental Management, 261, 110227.1-110227.8, https://doi.org/10.1016/j. jenvman.2020.110227

Shan, H. J. (2008). A Reestimation of China's Capital Stock K: In 1952 2006. Journal of Quantitative and Technical Economics, 25(10), 17-31, https://doi.org/10.13653/j.cnki. jqte.2008.10.003

Wang, B., Liu, G. T. (2015). Research on the Dynamics of Economic Growth under the Constraints of Energy Conservation and Emission Reduction--Empirical Research Based on BDDFM. On Economic Problems, (10):7-13+39, https://doi.org/10.16011/j.cnki.jjwt.2015.10.002

Wang, H. J. (2003). A Stochastic Frontier Analysis of Financing Constraints on Investment: The Case of Financial Liberalization in Taiwan. Journal of Business \& Economic Stats, 21(3), 406-419, https://doi.org/10.2139/ssrn.353640

Wang, Z. X., Zhang, H. Z., Gong, X. S., et al. (2018). Logistics Industry Agglomeration, Market Segmentation and Regional Green Economic Efficiency. Economic Survey, 35(05), 87-93, https://doi.org/10.15931/j.cnki.1006-1096.20180712.020

Yin, Q. M., Gu, Y. L. (2020). The Impact of Environmental Regulation on Green Economy Efficiency: A Threshold Model Analysis Based on the Interaction Effect of Industrial Structure. Journal of Industrial Technological Economics, 39(08), 141-147, https://doi.org/10.3969/j.issn.1004-910X.2020.08.018 
Zhang, Y. H., Cheng, J. L., Cheng, Y. (2018). Study on the Influence Mechanism of Environmental Regulation on Green Economy Efficiency in China-Empirical Analysis Based on Super Efficiency Model and Spatial Panel Metering Model. Resources and Environment in the Yangtze Basin, 27(11), 2407-2418, https://doi.org/10.11870/cjlyzyyhj201811002

Zhu, D. J. The New Concept of Green Economy and the Thinking of China's Green Economy. China Population, Resources and Environment, 2012, 22(05): 40-47. DOI: 1002-2104 (2012) 05-0040-08 